\title{
Vascular Disruption and the Role of Angiogenic Proteins After Spinal Cord Injury
}

\author{
Michelle T. L. Ng • Anthea T. Stammers • \\ Brian K. Kwon
}

Received: 31 July 2011 /Revised: 20 September 2011 /Accepted: 25 September 2011 /Published online: 13 October 2011

(C) Springer Science+Business Media, LLC 2011

\begin{abstract}
Spinal cord injuries (SCI) can result in devastating paralysis, for which there is currently no robustly efficacious neuroprotective/neuroregenerative treatment. When the spinal cord is subjected to a traumatic injury, the local vasculature is disrupted and the blood-spinal cord barrier is compromised. Subsequent inflammation and ischemia may then contribute to further secondary damage, exacerbating neurological deficits. Therefore, understanding the vascular response to SCI and the molecular elements that regulate angiogenesis has considerable relevance from a therapeutic standpoint. In this paper, we review the nature of vascular damage after traumatic $\mathrm{SCI}$ and what is known about the role that angiogenic proteins - angiopoietin 1 (Ang1), angiopoietin 2 (Ang2) and angiogenin - may play in the subsequent response. To this, we add recent work that we have conducted in measuring these proteins in the cerebrospinal fluid (CSF) and serum after acute $\mathrm{SCI}$ in human patients. Intrathecal catheters were installed in 15 acute SCI patients within $48 \mathrm{~h}$ of injury. CSF and serum samples were collected over the following 3-5 days and analysed for Ang1, Ang2 and angiogenin protein levels using a standard ELISA technique. This represents the first description of the endogenous expression of these proteins in an acute human SCI setting.
\end{abstract}

M. T. L. Ng • A. T. Stammers • B. K. Kwon ( $₫)$

International Collaboration on Repair Discoveries (ICORD),

Blusson Spinal Cord Centre, University of British Columbia, 818 West 10th Avenue,

Vancouver, BC, Canada V5Z 1M9

e-mail: Brian.Kwon@vch.ca

\section{B. K. Kwon}

Combined Neurosurgical and Orthopaedic Spine Program

(CNOSP), Department of Orthopaedics,

University of British Columbia,

Vancouver, BC, Canada
Keywords Spinal cord injury · Angiogenesis · Blood-spinal cord barrier · Angiopoietin · Angiogenin

\section{Introduction}

Each year, over 10,000 North Americans suffer acute and permanent paralysis after sustaining a traumatic spinal cord injury (SCI) [46]. Not only is an SCI one of the most physically disabling and psychologically devastating traumas that an individual can survive, the socioeconomic burden is enormous. Estimates of the annual medical and rehabilitative expenses are in the $\$ 1$ million range for individuals with high cervical cord paralysis [176]. Whilst historically this has been an injury of the youth, an ageing population prone to suffering cervical cord injuries after falls has altered the demographics of SCI, with a second peak of traumatic SCI appearing in the elderly population aged 65 and above [191].

The poor neurologic prognosis for SCI has prompted the development of a plethora of therapeutic strategies, many of which have shown promise in the laboratory setting $[122,123$, 185]. A handful of these have been evaluated in human clinical trials [78], but unfortunately, to date, none has proven to be convincingly efficacious at improving neurologic function for SCI patients [146]. Methylprednisolone remains the most extensively studied pharmacologic agent used for the treatment of acute SCI. However, mounting criticism around the execution and interpretation of data obtained from three landmark clinical trials (NASCIS I/II/III) has prompted many clinicians to abandon this drug, although it remains a 'treatment option' for acute SCI.

It has long been understood that when the spinal cord is injured (in, for example, a motor vehicle accident), local mechanical forces disrupt the complex vascular and cellular 
architecture of the cord but rarely transect the cord completely. This mechanical 'primary injury' is rapidly followed by an expanding cascade of 'secondary damage' mediated by pathophysiological mechanisms including ischemia, excitotoxicity, inflammation and oxidative stress (for review, see $[120,161]$ ). Attenuating these mechanisms to minimize secondary damage and afford 'neuroprotection' to regions of the spinal cord that have escaped the primary injury remains a principal therapeutic strategy.

This highlights the fundamental need to understand the pathophysiology of the secondary spinal cord damage that rapidly follows the primary injury. It has become evident from a vast body of literature in rodent models of SCI that the processes that mediate secondary injury are extremely complex. Our focus in this review will be on one aspect of secondary injury after SCI: The damage to local vasculature, its reparative response and the role that angiopoietins 1 (Ang1) and 2 (Ang2) and angiogenin may play in mediating this response.

\section{Vascular Supply of the Spinal Cord}

In humans, perfusion of the thoracic spinal cord is largely dependent on the arterial supply from the aorta [135]. Segmental radiculomedullary arteries feed the anterior and posterior spinal arteries, which are the main circumferential arteries outside the cord parenchyma (known as 'extrinsic' arteries) [21, 75, 188-190]. These give rise to 'intrinsic arteries' which include the central arteries as well as the pial plexus, which arborize into intramedullary arterioles before ending as terminal capillary beds. The intrinsic arteries reside within the spinal cord parenchyma and can be separated into two discrete circuits [21, 75, 188-190]. These circuits flow in opposite directions, creating a watershed region where terminal capillary beds of the two circuits overlap. The 'centrifugal circuit' is fed by the anterior spinal artery and supplies the central two thirds of spinal cord capillaries, including the dense capillary networks which support spinal grey matter and the inner regions of white matter [190]. The 'centripetal circuit' is fed by the posterior spinal artery as well as the many anastomoses arising from the anterior and posterior spinal arteries [190]. Vessels of this circuit supply much of the posterior (dorsal) spinal cord as well as most of the peripheral white matter and the dorsal grey horns [75, 188-190].

The centrifugal and centripetal vascular circuits meet in a complex network of terminal capillary beds. It is important to note that there is an approximately 5-fold increase in the density of such capillary beds which serve the grey matter as compared to that of the white matter [190]. This is likely attributable to the greater metabolic demands of cell bodies in the grey matter compared to axons of the white matter [188].

\section{Vascular Injury After Spinal Cord Injury}

It has been recognized for many years that trauma to the spinal cord disrupts its local vasculature. As early as 1914, Allen described the development of haemorrhage and oedema within the spinal cord after experimental SCI in dogs [5]. The primary insult causes immediate vascular disruptions at the injury epicentre [5, 26, 64, 89, 204]. This damage primarily affects the microvasculature, resulting in petechial haemorrhage observed at the injury epicentre immediately after injury [26, 42]. This haemorrhage starts near the central canal and is initially confined to the capillaries of the grey matter at $1 \mathrm{~h}$ post-injury, then spreads to the white matter by $2 \mathrm{~h}$ post-injury $[5,13,147]$. Most of the necrotic damage to endothelial cells occur during the first $24 \mathrm{~h}$ post-injury and can largely be attributed to the initial mechanical insult [26]. Further, endothelial cell loss after the first day, manifested as a decrease in intact blood vessel staining by rat endothelial cell antigen-1 [25, 130] and platelet-endothelial cell adhesion molecule (PECAM) [194], is attributed to apoptosis triggered by ischemia [26]. It has also been suggested that there is substantial oncotic endothelial cell death as a result of ionic imbalance due to the sustained activation of Trpm4 channels after SCI [60, 175]. Vessel density continues to decrease during the first 2 days, with little or no observable vessels at the injury epicentre [25, 194].

Angiogenesis is the process of blood vessel growth from existing vessels. This is distinct from the process of vasculogenesis, which is the de novo formation of blood vessels from mesenchymal tissue. After SCI, angiogenesis, presumably sprouting from vessels that are spared from the primary insult, starts 3 [42] to 4 days post-injury [25] and is observed for up to 1 week post-injury [25]. Revascularization to an extent that is comparable to control values [194] or even up 540\% [42] in vessel density has been reported at 7 days post-injury [42, 194]. However, these neovessels, which grow longitudinally through the injury epicentre [25], are not associated with neurons, astrocytes [25] or pericytes [61]. The restoration of Glut-1 transporters, which are responsible for transporting a constant supply of glucose across the blood-brain barrier (BBB) to metabolically fragile CNS neurons, has not been observed until the 2-week time point [194]. This suggests that although there is significant angiogenic growth during the early post-injury phases of SCI, these neovessels may not be fully functional, given the important role that astrocytes and pericytes have on vascular function within the nervous system. Perhaps as a consequence of the lack of integration of these neovessels 
into a functional neurovascular unit, there is subsequent pruning of these vessels at 2 weeks post-injury [25]. There is a more prolonged phase of angiogenesis from 4 weeks to 2 months post-injury, along with significant deposition of new basal lamina [130]. This further indicates that maturation and organization of neovessels occur after the first angiogenic phase and that much of the endothelial cell sprouts are pruned away based on the metabolic demand of the local area, with only a portion remaining to become stable, functionally integrated blood vessels.

The disruption of local microvasculature reduces perfusion of the remaining cord parenchyma [17, 63, 170]. Neurons have high metabolic requirements and are thus extremely vulnerable to reductions in perfusion and resultant periods of ischemia. This may be compounded by the loss of auto-regulatory mechanisms $[65,66,170]$ and systemic hypotension, which is common in acute SCI patients, as the result of hypovolemic and/or neurogenic shock $[22,66,170,171,183]$. At rest, neurons require more than three times the energy usage (in terms of ATP) than glial cells [10]. This difference increases to more than five times per second in a neuron that is generating action potentials [10]. This highlights the importance that ischemia holds in the neurological deterioration of SCI patients after the initial insult.

\section{The Blood-CNS Barrier}

It is important to realize that the consequences of the aforementioned microvascular damage are not limited to endothelial cell death and the loss of perfusion but also involves the breakdown of the blood-spinal cord barrier (BSCB). Anatomically, the blood-CNS barrier is manifested by several components of the capillary wall including endothelial cells, pericytes, astrocytes and the extracellular matrix. Endothelial cells in the CNS are overlapping, with tight junctions sealing paracellular spaces [23], no fenestrations [23, 47, 158] and minimal pinocytosis [169]. They also have an increased mitochondrial content, presumably to support transporters such as Glut-1 for glucose transport across this barrier [149]. Molecularly, the junctional complexes between adjacent endothelial cells are made of a combination of adherens and tight junctions. Adherens junctions are found in all vessel walls. They mediate the adherence of endothelial cells to one another by linking the actin cytoskeletons of adjacent cells [166]. Tight junctions are only found in blood-CNS interfaces. They are comprised of a complex of transmembrane proteins including junctional adhesion molecules [134], occludins [54] and claudins [56], which span the entire intercellular cleft, and intracellular accessory proteins including the zonula occludens [177], which link the transmembrane components to the cytoskeleton $[45,55]$.

Pericytes surround the endothelial cells and have a significant role in regulating BBB properties [9], as well as influencing endothelial cell proliferation, migration and differentiation $[9,156]$. Pericytes also mediate proper orientation and positioning of astrocytic foot processes around vessel walls [9]. The basal lamina, made of proteoglycan and laminin components, wraps around the layer of endothelial cells and pericytes, providing physical support for the vessel wall through interaction with other extracellular matrix components [97]. The basal lamina can also stimulate the expression of tight junction-related proteins to help maintain BBB function [163]. Astrocytic foot processes are juxtaposed against the basal laminacovered capillaries. They have a critical role in the formation and maintenance of the BBB $[1,79,85,100$, 137] and can modulate endothelial permeability via the secretion of chemical substances. Together, these components constitute a functional neurovascular unit-another example of how the vascular and nervous systems are physiologically linked.

Whilst the BSCB has slight structural and physiological differences from the BBB (some of which are highlighted in [14]), functionally the two play similar roles in protecting the CNS environment from the systemic circulation. There are a number of important aspects to this function, which include controlling ionic balance, regulating nutrient transport and restricting the passage of neurotoxic molecules and inflammatory cells.

The perception that the CNS is an immune privileged zone was first hypothesized in 1925 by Billingham and Boswell, who reported the lack of leukocyte infiltration in the brain [20]. Absolute immune privilege of the CNS has since been disputed with increasing evidence that the brain is indeed subjected to immunological surveillance (for review, see [32, 58]). However, there is clearly a relative difference in immune privilege between the CNS and peripheral tissues. The inflammatory response in the CNS under pathological conditions propagates with a different mechanism and in a different timeframe than that in peripheral tissues [8]. Furthermore, the number of immunological cells in the CNS is still greatly lower (if at all present) compared to the periphery (T-lymphocytes $[82,83,196]$, B-lymphocytes [76, 77, 116] and monocytes $[7,8])$.

The time course of BBB and BSCB breakdown in multiple sclerosis [104], after traumatic brain injury [4, 87] or SCI [41], has been reported to closely parallel the progression of neuroinflammation. The accumulation of immunological cells in perivascular spaces where basement membrane and astrocytic foot processes were displaced after SCI [182] suggests that BSCB breakdown may be 
involved in the expansion of the post-injury inflammatory response after SCI.

\section{Breakdown of the BSCB After SCI}

The conceptual integration of the nervous and vascular system is essential in understanding the pathophysiology of SCI and provides a basis for potential intervention strategies aimed at both nervous and vascular systems. In addition to the death of endothelial cells, there is extensive breakdown of the BSCB after SCI [17, 99, 102, 136, 147, 154, 159]. The lack of such a barrier protecting the spinal cord allows for the indiscriminate passage of cellular toxic molecules such as calcium [89, 164], excitatory amino acids [127, 198], free radicals [131], erythrocytes [5, 64, $89,99,145,147,184]$ and inflammatory mediators [41] into the injury penumbra, all of which may contribute to secondary injury after SCI. Although BSCB dysfunction has been reported largely from 2 [17, 99, 147, 154] to 4 weeks post-injury [136], chronic abnormalities have been observed at 8 weeks [182] and even 7 months post-injury [159].

In animal studies, BSCB breakdown after SCI is demonstrated by the extravasation of vascular tracers into the spinal cord parenchyma. This has been reported as early

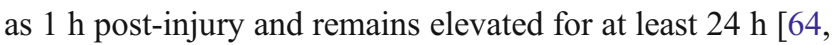
102, 147, 194]. This early peak in vascular leakage coincides with the acute inflammatory response [41], implicating the role of vascular permeability in the propagation of the inflammatory response after SCI by allowing inflammatory cells access into the injury penumbra. Increased BSCB permeability has also been observed between 3 and 7 days post-injury [17, 99, 154, 182, 194, 204], correlating with the initiation of angiogenesis and revascularization at the injury epicentre $[25,26,42,130$, 194]. The destabilization of existing vessels by an increase in vascular permeability is necessary for angiogenic remodelling to occur and is evident as a breach of tight junctions, displacement of astrocytic foot processes and separation of the basement membrane $[99,147,154]$. In the chronic phase of injury, up to 5.5 months, overlapping endothelial cell junctions are reformed [99], although the perivascular space continues to expand, with mis-aligned extracellular matrix, collagen layers and displaced astrocytic foot processes [99]. This suggests that despite endogenous reparative efforts, there are chronic morphological abnormalities in the BSCB after SCI.

Given the implications of vascular disruption on secondary injury, the mechanisms by which angiogenesis occurs and the BSCB restored are particularly relevant to the topic of how neuroprotection can be achieved in acute SCI. In the next section, we will discuss the role of the three angiogenic proteins-specifically angiopoietin 1, angiopoietin 2 and angiogenin -in the regulation of angiogenesis and the restoration of the BSCB after SCI.

\section{Introduction to the Angiogenic Proteins}

The angiopoietins are a family of growth factors that promote angiogenesis (for review, see [11, 203]). Ang1 and Ang2 are the best-characterized members of the angiopoietin family and are essential for the induction, maturation and maintenance of blood vessels. Angiogenin is a potent endothelial mitogen and belongs to the RNase A superfamily of ribonucleolytic proteins. It is also implicated in the pathogenesis of amyotrophic lateral sclerosis (ALS).

\section{Angiopoietin 1}

Ang1 was isolated by Davis et al. in 1996 [39] as a ligand for tyrosine kinase with Ig and endothelial growth factor homology domains (Tie) 2 receptors, which are predominantly expressed on endothelial cells [43, 44]. Ang1 is a 498-amino acid glycoprotein with a dimeric weight of approximately $70 \mathrm{kDa}[39,186]$. The Ang 1 protein consists of three distinct domains: a short amino terminus which forms a ring-like structure to super-cluster Ang1 homodimers together [40], a coiled-coil domain which mediates the formation of Ang1 homodimers via a disulphide bond at Cys245 [40, 155] and the carboxyl terminus which is homologous to the carboxyl terminus of fibrinogen, hence it being named the fibrinogen-like domain $[40,155]$. This domain is responsible for ligand activity [155] and contains the binding site to Tie2 [40, 49].

Ang1 is constitutively expressed at a low basal level in quiescent adult vasculature [39, 107, 132, 195, 197] by perivascular mural cells such as pericytes [181] and smooth muscle [107, 133]. Upon activation of its receptor Tie2, Ang1 induces pro-survival/anti-apoptotic effects on endothelial cells $[28,119,150,151]$. Ang1 binding induces auto-phosphorylation of Tie2, which activates downstream phosphatidylinositol 3-kinase (PI3K) and Akt [107, 151]. This has numerous downstream pro-survival effects, including the upregulation of survivin [35, 37, 70, 151], mammalian target of rapamycin [2] and the inhibition of caspases 3, 7, 9, BCL2 antagonist of cell death, mitochondrial second mitochondria-derived activator of caspase [27, 70, 151] and Forkhead box protein O1 [37]. Ang1 has been shown to interact with integrin to promote survival through a similar activation of Akt as well as various mitogenic protein kinases [35, 36]. Ang1 also modulates other survival signals such as extracellular signal-regulated kinase 1/2 (ERK1/2) [2, 71], stress-activated protein kinase (SAPK) and c-Jun NH2-terminal kinase (JNK) [71]. 
In addition to the role that it plays in promoting endothelial cell survival, Ang1 is crucial in maintaining vessel quiescence by limiting vascular permeability and controlling BSCB integrity [197]. Ang1 strengthens paracellular interactions and reduces the number and size of endothelial gaps [12] by inducing the expression of adhesive PECAM-1 [59] and tight junction proteins occludin [88] and ZO-2 [126]. Ang1 further reinforces vessel integrity by inhibiting the transcription of genes associated with vessel destabilization and remodelling [37]. By securing paracellular junctions, Ang1 effectively limits the progression the inflammatory response by restricting the passage of inflammatory cells from the bloodstream to CNS tissue [57]. Moreover, Ang1 activation of PI3K and Akt $[110,111]$ inhibits the expression of inflammatory cytokine nuclear factor-kB $(\mathrm{NF} \kappa \mathrm{B})$ [96] and adhesion molecules intercellular adhesion molecule 1, vascular cell adhesion molecule 1 and E-selectin $[59,110]$, which are required for the migration of inflammatory cells.

Although Ang1 has little to no proliferative effects on endothelial cells [52, 117, 195], it is essential in the later stages of angiogenesis, including the migration and organization of vessel components into mature, stable vessels [197]. Ang1 promotes the migration of vascular components to sites of angiogenesis $[2,24,52,53,72,106,162$, 195] and the organization of these components into tubulelike structures.

It is hypothesized that the ability of Ang1 signalling to both maintain the vasculature in a quiescent state as well as mediate angiogenesis may be attributed to differential ligand-receptor complexes that Ang1 and Tie2 receptors form in mobile versus confluent cells [53, 162, 205]. In mobile endothelial cells, Ang1 associates and binds to the extracellular matrix [200] via $\beta 1$-integrin [125] and releases adhesion molecules which promote cell motility and migration of vessel components [53, 162]. In contrast, when associated with confluent, mature endothelial cells, Ang1 mediates the formation of trans-associated Tie2 homotypic paracellular complexes to reinforce vascular integrity $[53,162,205]$.

\section{Angiopoietin 2}

Ang2 was first characterized in 1997 by Maisonpierre as the natural antagonist of Ang1 [132]. Whilst Ang1 is expressed at low basal levels constitutively, Ang2 expression is more actively regulated to modify and counteract Ang1 signalling. Ang1 and Ang2 share approximately 60\% homology in their amino acid sequence, as well as a common protein structure consisting of an amino terminal that modulates super-clustering, a coiled-coil domain for the formation of homodimers and a fibrinogen-like domain with ligand activity [16, 40, 132]. Ang1 and Ang2 bind to the same domain on Tie2 with similar affinities [15, 16, 132] and conformation [49]. However, they have opposite effects on receptor phosphorylation and activation.

Whilst binding of Ang1 to Tie2 induces receptor autophosphorylation and triggers downstream intracellular signalling pathways, the binding of Ang2 does not [155]. The differential effects that Ang1 and Ang2 have on receptor activation have been hypothesized to be due to their different abilities to form homotypic oligomers. Native Ang1 is largely found in superclusters of tetramers or higher order oligomers, whereas Ang2 is predominantly reported as homodimers [113, 155]. Receptor tyrosine kinases such as Tie2 have been reported to require multimerization for receptor activation [113, 155]. Thus, it is conceivable that although Ang2 dimers are able to bind to Tie 2 receptors, they may not be sufficient to elicit receptor auto-phosphorylation, effectively acting as an antagonist for Tie2. Interestingly, Ang2 is able to elicit agonistic effects when driven outside of its natural physiological state, such as at high concentrations, after prolonged exposure, as engineered high-order oligomers or in non-endothelial cells transfected with Tie2 [38, 40, 69, 108], supporting the hypothesis that the antagonistic role of Ang2 in its physiological state is at least in part mediated by its natural tendency to form lower order oligomers.

Ang2 is expressed by endothelial cells [195] and perivascular smooth muscle [133] at sites of active angiogenesis during the vessel destabilization process [38, $132,178]$. Its expression is induced by hypoxia [132, 133, 153], hypoxic factor HIF $1 \alpha$ [202] and vascular endothelial growth factor (VEGF) [148]. Ang2 is stored in intracellular Weibel-Palade bodies in endothelial cells along with von Willebrand factor, which is involved in haemostasis [50]. Stored Ang2 has a half-life of $18 \mathrm{~h}$ but can be secreted within minutes of stimulation [50]. In adults, Ang2 secretion is induced by various cytokines such as VEGF and basic fibroblast growth factor [133], inflammatory mediators tumour necrosis factor $\alpha$ and NFkB [109] or vasoactive molecule thrombin [50]. As the antagonist of Ang1, Ang2 induces the destabilization of vessel integrity [129, 148, 165], thus increasing BSCB permeability, but also thereby allowing vessels to undergo remodelling. Destabilization of existing vessels increases endothelial plasticity and is a primary prerequisite to vascular remodelling.

However, the result of these permeability changes also depends on the local cytokine milieu. In the presence of VEGF, Ang2 induces angiogenic sprouting, whilst in the absence of VEGF, Ang2 destabilization leads to vessel regression [18, 19, 86, 129]. Finally, Ang2 mediates the escalation of the inflammation response by increasing BSCB permeability to prime the endothelium and allow the passage of inflammatory cells through the vessel $[19$, 
51]. By loosening endothelial cell junctions, Ang2 facilitates the migration of inflammatory cells from the bloodstream into peripheral tissue [51, 109].

\section{Angiogenin}

Angiogenin is a 123-amino acid, $14-\mathrm{kDa}$ protein that potently induces angiogenesis and neovascularisation [48, $115,142,115,187]$. It was the first reported tumourderived angiogenic protein, characterized by Fett et al. in 1985 [48, 179]. Angiogenin shares 65\% homology to bovine pancreatic ribonuclease A [118, 179]. And although it has surprisingly low ribonucleolytic activity [3], the ribonucleolytic site on angiogenin appears to be essential for its angiogenic actions [33, 34, 93, 142, 172, 173].

Angiogenin is predominately expressed and released by endothelial cells, but it is also widely expressed by a variety of anchorage-dependent proliferating cells including aortic smooth muscle cells, fibroblasts and various tumour cells [139]. Angiogenin expression is induced by HIF $1 \alpha$ under cellular stress or hypoxic conditions [74, 144, 168]. A 170$\mathrm{kDa}$ receptor has been identified as the angiogenin receptor [94]. Upon binding, angiogenin is translocated to the nucleus where it regulates genes controlling the proliferation of endothelial cells by activation of ERK [128], Akt [114] and the SAPK/JNK pathways [201]. Angiogenin has also been reported to interact with 42-kDa smooth muscle type $\alpha$-actin [91, 92]. This induces the formation of angiogenin-actin complexes, which drive the degradation the extracellular matrix and basement membrane of blood vessels in order to promote the migration of vascular components [90, 93].

Aside from its prominent role in promoting tumour angiogenesis [48, 84, 115, 138, 139], angiogenin is wellcharacterized in the pathogenesis of ALS. Genetic mutations in angiogenin have been linked to both familial and sporadic ALS [30, 62, 105]. These ALS-associated mutants appear to have reduced or abolished survival-promoting activity, leading to the degeneration of motor neurons, an apparent symptom in the pathogenesis of ALS [168, 180, 199].

\section{Angiogenic Proteins as Treatment after SCI}

Vascular disruption, ischemia and BSCB permeability all contribute to secondary injury after SCI. Therefore, understanding angiogenesis and manipulating it therapeutically may potentially restore perfusion, reduce ischemic insults and reconstitute the BSCB to ultimately limiting secondary injury. Indeed, Ang1 as a treatment resulted in improved functional and histological outcomes following experimental SCI $[67,81]$. Ang1 with the integrin-binding peptide $\mathrm{C} 16$ was shown to rescue vasculature at the injury epicentre [67]. There was also an increased amount of spared white matter at both 7 and 42 days post-injury [67], although no further improvement was observed at 42 than 7 days. Decreased inflammation was observed as early as $24 \mathrm{~h}$ post-injury, suggesting that targeting early mechanisms such as vascular dysfunction can indeed result in long-term functional improvements by rescuing vasculature and reducing some aspects of inflammation very soon after SCI. This study is of particular clinical importance, as treatment did not begin until $4 \mathrm{~h}$ post-injury, which is a clinically realistic timeframe for a neuroprotective intervention in human SCI [67].

In another study, the combination of Ang1 and VEGF treatment by AAV viral transfection immediately after SCI decreased lesion volume and promoted vascular stability [81]. The treatment decreased oedema, demyelination and BSCB permeability, resulting in improved open-field locomotor function at 56 days post-injury [81]. Interestingly, the combination of Ang1 and other angiogenic molecules such as C16 or VEGF both resulted in synergistic functional outcome compared to each individual treatment, suggesting that in addition to the promotion of angiogenesis, the roles of Ang1 in the formation of stable vessel and regulation of BSCB permeability are crucial in limiting secondary injury after SCI.

Whilst there has been extensive investigation of angiogenic proteins as treatment after SCI, the endogenous expression of these proteins remains largely elusive. One recent report examined changes in several angiogenic growth factors in a rodent SCI model and reported both prolonged (VEGF) and transient (Ang1, PDGF, PlGF) decreases in gene expression up to 4 weeks post-injury [160]. However, the role that these endogenous changes have in the angiogenic response to SCI remains elusive.

\section{Changes in Angiogenic Proteins After Acute Human SCI}

The discussion to this point has revolved around what has been studied and reported with respect to Ang1, Ang2 and angiogenin in animal models of SCI. The vast majority of our scientific understanding of the pathophysiology of secondary injury is derived from such animal studies. However, therapies that have been shown to be effective in rodent models of SCI have historically been unsuccessful at demonstrating efficacy when translated to human clinical trials. Whilst there are many potential reasons for this, one is that important biological differences may exist between the pathophysiology of such animal models and that of the human condition. 
Studying the biology of human SCI is obviously considerably more difficult than in animal models given that cord specimens can only be obtained postmortem. Our studies have therefore utilized what might be considered 'the next best thing'-cerebrospinal fluid (CSF). We recognize that this is an indirect measure of what is happening within the spinal cord itself and that it would be challenging to interpret data from human CSF in relation to when the proteins are actually being released or extruded from the injury site. However, animal studies that have compared parenchymal and CSF levels of specific molecules have shown that they do correspond, albeit with much lower levels in the CSF than the cord parenchyma [73, 193]. In this present study, we investigated the temporal changes in three angiogenic proteins: Ang1, Ang2 and angiogenin following acute human SCI. We evaluated the protein levels in both CSF and serum samples of SCI patients and non-SCI controls. We sought to characterize the patterns of expression of these proteins and how their levels might be influenced by injury severity and/or hold implications for neurological recovery after SCI.

\section{Materials and Methods}

Patients from a single level 1 regional trauma institution were enrolled in a clinical trial in which lumbar intrathecal catheters were inserted to measure CSF pressure and obtain CSF samples [121]. The clinical trial protocol was approved by the university human ethics committee and was registered on ClinicalTrials.gov (ID: NCT00135278). Inclusion criteria for enrolment included (1) SCI between C3 and T11 inclusive; (2) ASIA impairment score (AIS) A-motor and sensory complete SCI, B-motor complete, sensory incomplete SCI or $\mathrm{C}$-motor and sensory incomplete SCI upon presentation; (3) presentation within $48 \mathrm{~h}$ of injury and (4) ability to provide a valid and reliable baseline neurological exam. Patients with concomitant head injuries, major trauma to the chest, pelvis or extremities that required invasive intervention and those who were too sedated or intoxicated to give a valid neurologic examination were excluded. The patients provided informed consent to participate in the study in which an intrathecal drain was installed and left in situ for 3 to 5 days. To obtain control CSF from the 'non-SCI' condition, a direct lumbar dural puncture was performed in individuals undergoing lumbar spine surgery.

Upon presentation, patients were evaluated by a clinical research nurse, and a neurological examination was performed to assign a baseline AIS and ASIA motor score. Long-term outcome was measured at 6 months and 1 year post-injury with parameters used in the initial baseline neurological testing including AIS, ASIA motor score and the last normal sensory level.

Intrathecal catheters (PERIFIX ${ }^{\circledR}$ Custom Epidural Anaesthesia Kit; B. Braun Medical Inc., Bethlehem, PA, USA) were inserted at $\mathrm{L} 2 / 3$ or $\mathrm{L} 3 / 4$, and 3 to $4 \mathrm{ml}$ of CSF was collected every 6 to $8 \mathrm{~h}$ for 3 to 5 days using a strict aseptic technique. For non-SCI controls undergoing lumbar spine surgery, a sample of CSF was obtained via needle puncture of the dura at the end of their surgery. Samples were immediately centrifuged at $1,000 \mathrm{rcf}$ for $10 \mathrm{~min}$. The supernatant was aliquoted, snap-frozen in an ethanol and dry ice bath and stored at $-80^{\circ} \mathrm{C}$ until analysis. Blood samples were drawn in both SCI patients and non-SCI controls at the same times that CSF samples were collected. The blood samples were left to clot at room temperature for $15 \mathrm{~min}$ and then centrifuged at 10,000 $\mathrm{rcf}$ for $5 \mathrm{~min}$. The serum was aliquoted, frozen and stored at $-80^{\circ} \mathrm{C}$ until analysis.

The CSF and serum samples were analysed using standard quantitative sandwich ELISA kits for Ang1 (Quantikine ${ }^{\circledR}$ Human Angiopoietin-1) and Ang2 (Quantikine ${ }^{\circledR}$ Human Angiopoietin-2) and a microparticle-based multiplex ELISA kit for Angiogenin (Fluorokine ${ }^{\circledR}$ MAP Human Angiogenesis Base Kit A and Angiogenin bead set). All kits were manufactured by R\&D Systems Inc., Minneapolis, MN, USA. For SCI patients, up to 15 CSF and blood samples taken between 8 and $120 \mathrm{~h}$ post-injury were analysed. A single baseline sample was analysed for non-SCI controls. All samples were run in duplicate.

Statistical analysis was performed using SPSS Statistics 17.0 software. Normal distribution in the data was tested using the Shapiro-Wilk test, and equality of variances between groups was tested using the Levene test. KruskalWallis $H$ test was used to compare protein levels with baseline AIS. The Friedman test was used to examine temporal changes in individual patients. The MannWhitney $U$ test was used to compare values between SCI patients and non-SCI controls at each time point. Spearman's correlation was used to investigate relationships between protein levels and outcome parameters at 6 months or 1 year post-injury.

\section{Results}

For this study, we analysed 15 SCI patients equally divided amongst injury severity, with five AIS A, five AIS B and five AIS $\mathrm{C}$ at baseline (Table 1). Twelve individuals suffered cervical SCI, whilst three suffered thoracic SCI. The average age was 41.7 years, with 13 males and two females. Five patients were injured by motor vehicle accidents, five during sporting activities, four from falls and one resulting from a direct blow to the 
Table 1 Demographics of SCI patients enrolled in the current study

\begin{tabular}{|c|c|c|c|c|c|c|c|c|c|}
\hline \multirow[t]{2}{*}{ Subject } & \multirow{2}{*}{$\begin{array}{l}\text { Age/ } \\
\text { sex }\end{array}$} & \multirow{2}{*}{$\begin{array}{l}\text { Injury } \\
\text { level }\end{array}$} & \multirow[t]{2}{*}{ Mechanism of injury } & \multicolumn{3}{|c|}{ Upon presentation } & \multicolumn{3}{|c|}{ 6-month or 1-year follow-up } \\
\hline & & & & AIS & $\begin{array}{l}\text { ASIA motor } \\
\text { score }\end{array}$ & $\begin{array}{l}\text { Last normal sensory } \\
\text { level }\end{array}$ & AIS & $\begin{array}{l}\text { ASIA motor } \\
\text { score }\end{array}$ & $\begin{array}{l}\text { Last normal sensory } \\
\text { level }\end{array}$ \\
\hline SCI 1 & $42 / \mathrm{M}$ & C6-7 & Transport & B & 19 & C5 & B & 27 & C6 \\
\hline SCI 2 & $64 / F$ & C5-6 & Sports & $\mathrm{C}$ & 41 & $\mathrm{C} 5$ & $\mathrm{D}$ & 98 & $\mathrm{C} 2$ \\
\hline SCI 3 & $66 / \mathrm{M}$ & $\mathrm{C} 4-5$ & Fall & $\mathrm{C}$ & 20 & T9 & $\mathrm{C}^{\mathrm{a}}$ & $49^{\mathrm{a}}$ & $\mathrm{C} 4^{\mathrm{a}}$ \\
\hline SCI 4 & $60 / \mathrm{M}$ & $\mathrm{C} 4-5$ & Fall & B & 6 & $\mathrm{C} 5$ & $\mathrm{D}$ & 80 & $\mathrm{C} 4$ \\
\hline SCI 5 & $46 / \mathrm{M}$ & C4-5-6 & Transport & $\mathrm{C}$ & 5 & $\mathrm{C} 2$ & $\mathrm{C}^{\mathrm{a}}$ & 71 & $\mathrm{C} 5$ \\
\hline SCI 6 & $20 / \mathrm{M}$ & C6-7 & Transport & $\mathrm{B}$ & 30 & C6 & $\mathrm{C}^{\mathrm{a}}$ & $86^{\mathrm{a}}$ & $\mathrm{T} 6^{\mathrm{a}}$ \\
\hline SCI 7 & $39 / \mathrm{M}$ & $\mathrm{C} 3-4$ & Sports & $\mathrm{C}$ & 33 & $\mathrm{C} 3$ & $\mathrm{D}$ & 83 & $\mathrm{C} 4^{\mathrm{a}}$ \\
\hline SCI 8 & $54 / \mathrm{M}$ & C5-6 & Transport & $\mathrm{C}$ & 36 & $\mathrm{C} 4$ & $\mathrm{D}^{\mathrm{a}}$ & $65^{\mathrm{a}}$ & $C 5^{\mathrm{a}}$ \\
\hline SCI 9 & $19 / \mathrm{F}$ & $\mathrm{T} 10$ & Fall & A & 50 & T9 & A & 50 & $\mathrm{~T} 7$ \\
\hline SCI 10 & $38 / \mathrm{M}$ & $\mathrm{C} 5$ & $\begin{array}{l}\text { Struck on the back of } \\
\text { head }\end{array}$ & $\mathrm{B}$ & 17 & $\mathrm{C} 5$ & $\mathrm{D}^{\mathrm{a}}$ & $15^{\mathrm{a}}$ & $\mathrm{C} 6^{\mathrm{a}}$ \\
\hline SCI 11 & $22 / \mathrm{M}$ & L1 & Transport & A & 60 & $\mathrm{C} 2$ & $\mathrm{~A}^{\mathrm{a}}$ & $66^{\mathrm{a}}$ & $\mathrm{L}^{\mathrm{a}}$ \\
\hline SCI 12 & $25 / \mathrm{M}$ & $\mathrm{C} 7$ & Sports & $\mathrm{A}$ & 43 & $\mathrm{C} 7$ & $\mathrm{C}$ & 58 & $\mathrm{C} 7^{\mathrm{a}}$ \\
\hline SCI 13 & $51 / \mathrm{M}$ & $\mathrm{T} 10$ & Fall & A & 50 & $\mathrm{~T} 11$ & $\mathrm{~A}^{\mathrm{a}}$ & $50^{\mathrm{a}}$ & $\mathrm{T} 11^{\mathrm{a}}$ \\
\hline SCI 14 & $55 / \mathrm{M}$ & C6-7 & Sports & A & 27 & C6 & UNK & UNK & UNK \\
\hline SCI 15 & $25 / \mathrm{M}$ & $\mathrm{C} 5$ & Sports & $\mathrm{B}$ & 13 & $\mathrm{C} 4$ & $\mathrm{~B}^{\mathrm{a}}$ & UNK & $\mathrm{C} 4^{\mathrm{a}}$ \\
\hline
\end{tabular}

UNK unknown, where follow-up neurological testing was not performed or has not yet been performed at the time this manuscript was prepared ${ }^{\text {a }}$ Six-month follow-up

back of the head (Table 1). The CSF and serum of these 15 patients were compared against eight 'non-injured' control subjects. This population averaged 60.1 years in age and included four males and four females (Table 2).

The concentrations of Ang1, Ang2 and angiogenin were evaluated at 12 -h intervals from $24 \mathrm{~h}$ to 5 days post-injury (Figs. 1, 2 and 3). The values within groups did not display normal distribution (Shapiro-Wilk test), and variances between groups were unequal (Levene test); hence, non-parametric statistical tests were used for all comparisons. No significant differences in Ang1, Ang2 or angiogenin concentrations were found between AIS A, B or C patients at any time point post-injury (including baseline). Thus, the data from all injury severities were pooled to compare the SCI condition (AIS A, B and C) against non-SCI controls. For the nonSCI controls, only a single CSF and serum sample was obtained, and we made the assumption that the concentrations would remain largely unchanged over time in these individuals.

For Ang1, both the CSF and serum levels of Ang1 at the earliest time point were analysed, around $24 \mathrm{~h}$ postinjury $(p<0.05$, Mann-Whitney $U$ test) (Fig. 1). The median Ang1 value in CSF in SCI patients at this time was $50.03 \mathrm{pg} / \mathrm{ml}$ [interquartile range (IQR) 43.70-84.19], whereas the median value for non-SCI controls was $39.72 \mathrm{pg} / \mathrm{ml}$ [IQR 35.54-48.31]. In the serum, the median value for SCI patients was $4,661.70 \mathrm{pg} / \mathrm{ml}$ [IQR 3,959.77-
Table 2 Demographics of nonSCI controls enrolled in the current study

\begin{tabular}{lll}
\hline Subject & Age/sex & Diagnosis \\
\hline CTRL 1 & 49/M & L4-5 recurrent disc herniation \\
CTRL 2 & 85/F & L2-3, 3-4, 4-5, 5-S1 stenosis \\
CTRL 3 & $52 / \mathrm{F}$ & Right S1 radiculopathy \\
CTRL 4 & $68 / \mathrm{F}$ & Degenerative L3-4 spondylolisthesis \\
CTRL 5 & 45/M & L5-S1 disc herniation \\
CTRL 6 & $61 / \mathrm{F}$ & L5-6 disc herniation \\
CTRL 7 & $62 / \mathrm{M}$ & L5-S1 degenerative disc disease with neural foraminal stenosis \\
CTRL 8 & 59/M & L3-4 spinal stenosis; L4-5 degenerative spondylolisthesis \\
\hline
\end{tabular}




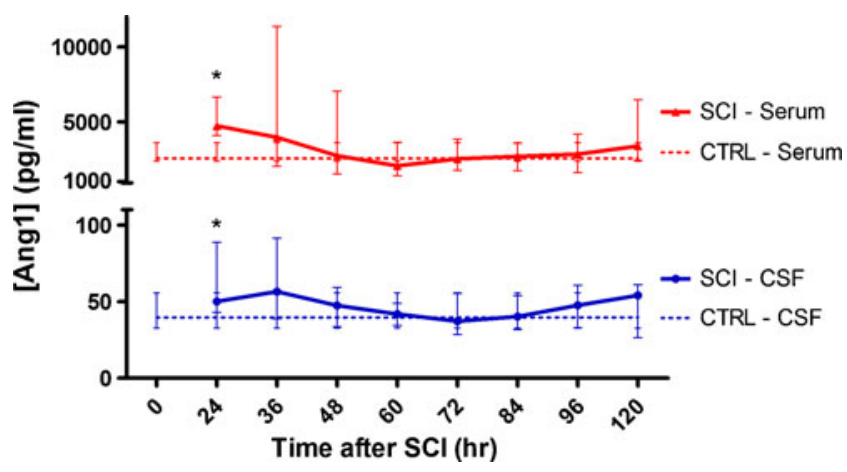

Fig. 1 Median Ang1 protein levels in CSF and serum after acute human SCI. SCI patients showed significantly higher Ang1 values than non-SCI controls in both CSF and serum at $24 \mathrm{~h}$ post-injury. Median CSF value for SCI patients at $24 \mathrm{~h}$ post-injury was $50.03 \mathrm{pg} /$ $\mathrm{ml}$ whereas median value for non-SCI controls was $39.72 \mathrm{pg} / \mathrm{ml}$. Median serum value at $24 \mathrm{~h}$ post-injury for SCI patients was $4,661.70 \mathrm{pg} / \mathrm{ml}$, and median value for non-SCI controls was $2,542.25 \mathrm{pg} / \mathrm{ml}$. Blue lines (circles) represent CSF values and red lines (triangles) represent serum values. SCI patients are represented with solid lines, and non-SCI controls are represented with dotted lines. Data presented as median $\pm \mathrm{IQR} .{ }^{*} p<0.05$, Mann-Whitney $U$ test

6,226.92] and 2,542.25 pg/ml [IQR 2,426.67-3,306.99] in non-SCI controls. These elevations in Ang1 diminished over the subsequent $12 \mathrm{~h}$, and by $36 \mathrm{~h}$ post-injury, SCI and control levels were no longer significantly different in CSF or serum. There were also no statistically significant correlations between Ang1 levels and the 6- and 12-month neurologic outcomes.

In contrast to the early peak in Ang1, a delayed and prolonged increase in CSF Ang2 expression was observed

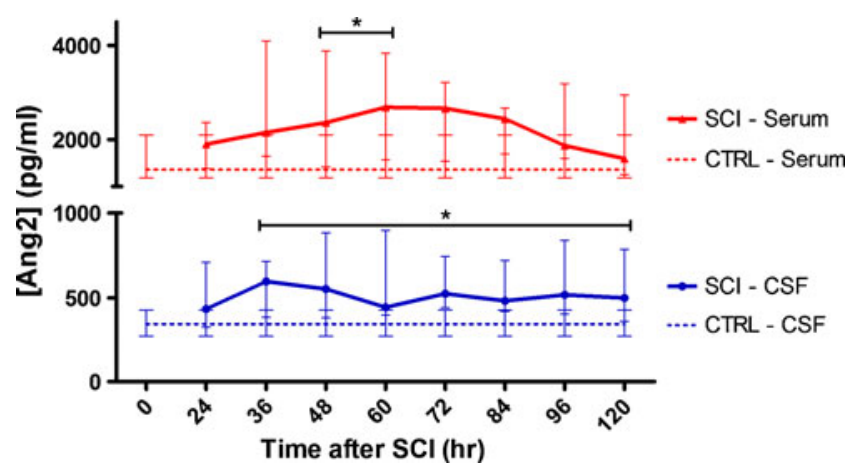

Fig. 2 Median Ang2 protein levels in CSF and serum after acute human SCI. SCI patients showed significantly higher Ang2 values from $36 \mathrm{~h}$ post-injury until the end of the study period at $120 \mathrm{~h}$ postinjury in the CSF. Serum samples from SCI patients were also significantly higher than non-SCI controls between 48 and $60 \mathrm{~h}$ postinjury. The peak in CSF at $36 \mathrm{~h}$ post-injury in SCI was $599.16 \mathrm{pg} / \mathrm{ml}$ compared to $344.80 \mathrm{pg} / \mathrm{ml}$ in non-SCI controls. The peak in serum is observed at $60 \mathrm{~h}$ post-injury, with SCI value at $2685.61 \mathrm{pg} / \mathrm{ml}$ and non-SCI control value at $1,358.77 \mathrm{pg} / \mathrm{ml}$. Blue lines (circles) represent CSF values, and red lines (triangles) represent serum values. SCI patients are represented with solid lines, and non-SCI controls are represented with dotted lines. Data presented as median $\pm \mathrm{IQR}$. ${ }^{*} p<$ 0.05, Mann-Whitney $U$ test
(Fig. 2). Increased Ang2 levels were observed in SCI patient CSF from $36 \mathrm{~h}$ post-injury and stay upregulated until the end of the study period. The maximal difference in CSF between SCI patients and non-SCI controls is observed at $36 \mathrm{~h}$ post-injury, with SCI patient median at $599.16 \mathrm{pg} / \mathrm{ml}$ [IQR 394.19-688.38] and non-SCI control median at $344.80 \mathrm{pg} / \mathrm{ml}$ [IQR 280.05-392.72]. The maximal difference in serum levels is observed at $60 \mathrm{~h}$ postinjury, with SCI patient median at 2,685.61 $\mathrm{pg} / \mathrm{ml}$ [IQR $1,588.76-3,823.93]$ and non-SCI control median at $1,358.77 \mathrm{pg} / \mathrm{ml}$ [IQR $1,207.85-2,080.15]$. The differences between SCI and non-SCI values were statistically significant in CSF from $36 \mathrm{~h}$ until the end of the study and in serum between 48 and $60 \mathrm{~h}$ post-injury $(p<0.05$, MannWhitney $U$ test). Again, no significant correlations were found between Ang2 values and the neurologic outcome at 6 months or 1 year post-injury.

For angiogenin within the CSF, the concentration in SCI patients appeared to decrease starting around $36 \mathrm{~h}$ postinjury, and between 72 and $84 \mathrm{~h}$ post-injury, levels were significantly lower than in non-SCI controls $(p<0.05$, Mann-Whitney $U$ test) (Fig. 3). Maximal difference is observed at $72 \mathrm{~h}$ post-injury with median value for SCI at $6.73 \mathrm{ng} / \mathrm{ml}$ [IQR 5.27-7.46] and median value for non-SCI controls at $8.81 \mathrm{ng} / \mathrm{ml}$ [IQR $8.45-10.32$ ]. In the serum, there appear to be no changes until $60 \mathrm{~h}$ post-injury, with an increasing trend from 60 to $120 \mathrm{~h}$ post-injury. Median serum value for SCI at $120 \mathrm{~h}$ post-injury was $465.17 \mathrm{ng} / \mathrm{ml}$ [IQR 402.77-631.82], and non-SCI median was 232.18 [IQR 204.11-316.50]. However, these values were not significantly different between SCI and non-SCI controls $(p<0.05$, Mann-Whitney $U$ test $)$.

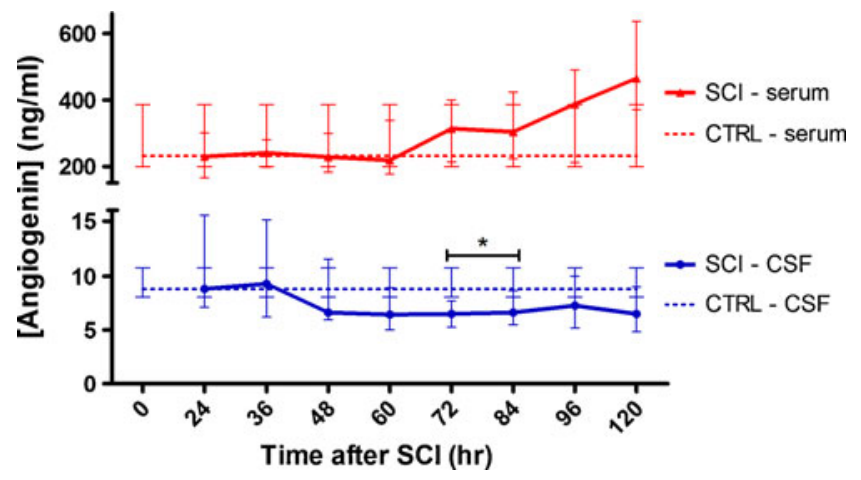

Fig. 3 Median angiogenin protein levels in CSF and serum after acute human SCI. SCI patients showed significantly lower angiogenin values in CSF between 72 and $84 \mathrm{~h}$ post-injury. No significant differences were observed between SCI patients and non-SCI controls in serum samples. Median CSF value in SCI patients at $72 \mathrm{~h}$ postinjury was $6.73 \mathrm{ng} / \mathrm{ml}$, and median for non-SCI controls was $8.81 \mathrm{ng} /$ $\mathrm{ml}$. Blue lines (circles) represent CSF values, and red lines (triangles) represent serum values. SCI patients are represented with solid lines, and non-SCI controls are represented with dotted lines. Data presented as median \pm IQR. ${ }^{*} p<0.05$, Mann-Whitney $U$ test 


\section{Discussion of Angiogenic Changes After Human SCI}

The expression of angiogenic and BSCB-integritypromoting proteins in the acute phase post-SCI could limit the spread of secondary damage by tightening the interactions between endothelial cells and mural cells to close the paracellular junctions in vessel walls, therefore preserving the BSCB. This could also eliminate the extra-vascular space which has been reported to become a conduit for inflammatory cells invading the site of injury [182]. Furthermore, by preserving distal circulation in the overlapping vascular networks of the spinal cord, adequate perfusion to the site of injury could be maintained. In an attempt to investigate the role of angiogenesis in the acute phase after SCI, we have previously measured the levels of another potent angiogenic factor, VEGF, using a similar biochemical assay but were not able to detect it at any measurable levels in the CSF of the current series of acute SCI patients [124].

A decrease in the expression of Ang1 mRNA has been reported after acute SCI in rats from $6 \mathrm{~h}$ to 2 weeks postinjury [160]. Ang1 activity early after SCI could help preserve the integrity of the $\mathrm{BSCB}$, which when compromised promotes the invasion of inflammatory cells and other toxic blood products into the injury penumbra [147, 154, 194]. Although a transient increase in Ang1 expression is observed at $24 \mathrm{~h}$, this is likely due to the release of Ang1 from damaged endothelial cells into the CSF as a result of the initial mechanical impact. The absence of a sustained increase in Ang1 levels within the CSF in the current study supports the contention of investigators such as Han et al. [67] and Herrera et al. [81] who administered Ang1 in the hopes of increasing angiogenesis and restoring the integrity of the BSCB after acute SCI. These authors showed that Ang1 alone or in combination with another angiogenic factor resulted in functional improvements after experimental SCI $[67,81]$.

Conversely, the prolonged upregulation of Ang2 expression from $36 \mathrm{~h}$ post-injury observed in the current study could exacerbate secondary injury by destabilizing endothelial junctions to increase BSCB permeability. A delayed angiogenic response after SCI has been reported in several studies, ranging from 3 to 7 days $[17,99,154,182,194$, 204]. No further neurological changes were correlated to the new angiogenic status in these studies, adding evidence to support that although endogenous reparative response of the damaged tissue and vasculature is observed after acute SCI, these neovessels fail to integrate into a functional neurovascular unit. Furthermore, it is likely that the increase in BSCB permeability during the early stages of injury, in addition to the lack of continued robust Ang1 response, contributes to the exacerbation of secondary injury. Angiogenesis and the maintenance of the BSCB after acute traumatic SCI is not only a neuroprotective strategy - to preserve remaining neurons and glia and prevent further cell death by ischemia - but blood vessels also provide trophic support and a scaffold for both endogenous and potential regeneration strategies [143].

However, along with stimulating angiogenesis, this prominent increase in Ang2 after SCI may allow the passage of deleterious inflammatory cells and cytokines, as well as cytotoxic molecules into the injury penumbra, exacerbating secondary injury. A marked inflammatory response has been established from 3 to 7 days postinjury $[41,154,194]$, which coincides with revascularization of the injury epicentre $[25,42,130,194]$. The time course of BSCB repair also closely parallels that of the appearance of the glial scar [130]. It has recently been reported that a subpopulation of pericytes, perhaps those which proliferate during the first angiogenic stage but are not integrated into a functional neurovascular unit, leave the vessel wall, trans-differentiate to express fibroblast markers, migrate into the lesion epicentre and are responsible for a majority of the extracellular deposition of the glial scar sealing the injury epicentre [61].

There is a significant decrease in the CSF expression of angiogenin between SCI and non-SCI control groups from 72 to $84 \mathrm{~h}$ post-injury, substantial inter-individual variation and statistical noise may mask any potential differences between SCI patients and non-SCI controls. However, the decreased expression of angiogenin after SCI suggests that the angiogenic changes that occur in the acute phase postinjury are not driven by the same mechanism as tumorigenic angiogenesis that has been reported to be associated with angiogenin $[48,84,138]$.

The temporal changes examined in this study represent the changes of all sample SCI patients compared to all non$\mathrm{SCI}$ controls. However, it has been reported that there is a substantial variation in inter-individual protein expression levels in CSF even in healthy individuals [167]. We too observed considerable variation in our SCI patients and uninjured controls. Certain patterns of change present after SCI in our sample population could potentially have been masked by this great inter-individual variation, as it would be logistically impossible to acquire a non-SCI baseline measure for each SCI patient enrolled in this study to use as a comparison for their post-SCI expression values. However, a majority of the values recorded for our non-SCI controls reflect the values of controls which have previously been reported (Table 3) [6, 29, 31, 68, 80, 84, 95, 98, $101,103,112,138,140,141,152,157,174,192]$.

In the current study, all protein levels in serum were considerably higher, by orders of magnitude, than in CSF. However, the serum and CSF concentrations did not appear to be changing in parallel, which suggests that the changes seen in the CSF are indeed local CNS changes, and not a 
Table 3 Summary of serum or CSF Ang1, Ang2 and angiogenin values reported in the current study and in literature

\begin{tabular}{|c|c|c|c|c|}
\hline Author & Study & Population & Serum $(\mathrm{ng} / \mathrm{ml})$ & CSF (ng/ml) \\
\hline \multicolumn{5}{|l|}{ Ang1 } \\
\hline \multirow[t]{3}{*}{$\mathrm{Pg}$} & \multirow[t]{3}{*}{ Current study } & \multirow[t]{2}{*}{$\operatorname{SCI}(n=15)$} & At $24 \mathrm{~h}$ post-injury: & At $24 \mathrm{~h}$ post-injury: \\
\hline & & & $4.66[3.96-6.23]$ & $50.03[43.70-84.19]$ \\
\hline & & $\operatorname{Ctrl}(n=8)$ & $2.54[2.43-3.31]$ & $39.72[35.54-48.31]$ \\
\hline \multirow[t]{2}{*}{ Joshi } & \multirow[t]{2}{*}{ Clin Biochem. 2011} & Multiple myeloma $(n=62)$ & $36.28(19.8-44.0)$ & \\
\hline & & $\operatorname{Ctrl}(n=50)$ & $37.05(35.7-39.2)$ & \\
\hline Reed & Kidney International. 2011 & $\begin{array}{l}\text { Autosomal dominant polycystic } \\
\text { kidney disease }(n=71)\end{array}$ & $35.52 \pm 21.03$ & \\
\hline \multirow[t]{2}{*}{ Choe } & \multirow[t]{2}{*}{ Joint Bone Spine. 2010} & Bencet's disease $(n=59)$ & $284.5 \pm 101.2$ & \\
\hline & & $\operatorname{Ctrl}(n=65)$ & $237.1 \pm 76.4$ & \\
\hline \multirow[t]{3}{*}{ Han } & \multirow[t]{3}{*}{ Hypertens Pregnancy. 2010} & Preeclampsia $(n=16)$ & Plasma & \\
\hline & & & $12.65(1.27-17.5)$ & \\
\hline & & $\operatorname{Ctrl}(n=29)$ & $10.35(1.43-31.89)$ & \\
\hline \multirow[t]{2}{*}{ Karapinar } & \multirow[t]{2}{*}{ Heart and Vessels. 2010} & Hypertension $(n=49)$ & $26.95 \pm 11.63$ & \\
\hline & & $\operatorname{Ctrl}(n=21)$ & $43.34 \pm 9.77$ & \\
\hline \multirow[t]{2}{*}{ Anagnostopoulos } & \multirow[t]{2}{*}{ Br J Haematol. 2007} & $\begin{array}{l}\text { Waldenstrom's macroglobulinemia } \\
\quad(n=56)\end{array}$ & $18.4(1.7-107.5)$ & \\
\hline & & $\operatorname{Ctrl}(n=30)$ & $23.2(0.1-45.9)$ & \\
\hline \multicolumn{5}{|l|}{ Ang2 } \\
\hline \multirow[t]{3}{*}{$\mathrm{Pg}$} & \multirow[t]{3}{*}{ Current study } & $\operatorname{SCI}(n=15)$ & At $60 \mathrm{~h}$ post-injury: & At $36 \mathrm{~h}$ post-injury: \\
\hline & & & $2.69[1.59-3.82]$ & 599.16 [394.19-688.38] \\
\hline & & $\operatorname{Ctrl}(n=8)$ & $1.36[1.21-2.08]$ & $344.80[280.05-392.72]$ \\
\hline \multirow[t]{2}{*}{ Joshi } & \multirow[t]{2}{*}{ Clin Biochem. 2011} & Multiple myeloma $(n=62)$ & $4.45(2.1-13.25)$ & \\
\hline & & $\operatorname{Ctrl}(n=50)$ & $1.67(0.25-3.45)$ & \\
\hline Reed & Kidney International. 2011 & $\begin{array}{l}\text { Autosomal dominant polycystic } \\
\text { kidney disease }(n=71)\end{array}$ & $2.35 \pm 0.96$ & \\
\hline \multirow[t]{3}{*}{ Han } & \multirow[t]{3}{*}{ Hypertens Pregnancy. 2010} & Preeclampsia $(n=16)$ & Plasma & \\
\hline & & & $11.2(2.3-21.9)$ & \\
\hline & & Ctrl $(n=29)$ & $3.9(1.4-14.7)$ & \\
\hline \multirow[t]{2}{*}{ Helfrich } & \multirow[t]{2}{*}{ Clin Cancer Res. 2009} & Melanoma $(n=98)$ & $2.03[1.71-3.28]$ & \\
\hline & & $\operatorname{Ctrl}(n=82)$ & $1.24[0.93-1.57]$ & \\
\hline \multirow[t]{2}{*}{ Moreau } & Amyotroph Lateral Scler. 2009 & $\operatorname{ALS}(n=40)$ & & $86.75[67-132]$ \\
\hline & & $\operatorname{Ctrl}(n=40)$ & & $82.5[30-147]$ \\
\hline Anagnostopoulos & Br J Haematol. 2007 & $\begin{array}{l}\text { Waldenstrom's macroglobulinemia } \\
\quad(n=56)\end{array}$ & $2.6(1.0-11.3)$ & \\
\hline & & $\operatorname{Ctrl}(n=30)$ & $1.4(0.6-5.1)$ & \\
\hline Angiogenin & & & & \\
\hline $\mathrm{Ng}$ & Current study & $\mathrm{SCI}(n=15)$ & At $120 \mathrm{~h}$ post-injury: & At $72 \mathrm{~h}$ post-injury: \\
\hline & & & $465.17[402.77-631.82]$ & $6.73[5.27-7.46]$ \\
\hline & & $\operatorname{Ctrl}(n=8)$ & $232.18[204.11-316.50]$ & $8.81[8.45-10.32]$ \\
\hline Moreau & Amyotroph Lateral Scler. 2009 & $\operatorname{ALS}(n=40)$ & & $288.0[267-307]$ \\
\hline & & $\operatorname{Ctrl}(n=40)$ & & $282.5[244-326]$ \\
\hline Ilzecka & Acta Clin Croat. 2008 & $\operatorname{ALS}(n=20)$ & & $0.328(0.208-0.45)$ \\
\hline & & $\operatorname{Ctrl}(n=15)$ & & $0.286(0.153-0.483)$ \\
\hline Patel & Ann Med. 2008 & Chronic heart failure $(n=109)$ & $466[314-739]$ & \\
\hline & & $\operatorname{Ctrl}(n=112)$ & $310[264-376]$ & \\
\hline Anagnostopoulos & Br J Haematol. 2007 & $\begin{array}{l}\text { Waldenstrom's macroglobulinemia } \\
\quad(n=56)\end{array}$ & $398.1(147.4-1,180.6)$ & \\
\hline & & $\operatorname{Ctrl}(n=30)$ & $226.9(145.8-398.7)$ & \\
\hline Huang & Eur Neurol. 2007 & $\begin{array}{l}\text { Acute cerebral infarction } \\
(n=30)\end{array}$ & $\begin{array}{l}\text { At } 48 \mathrm{~h}: \\
415.1 \pm 76.8\end{array}$ & \\
\hline
\end{tabular}


Table 3 (continued)

\begin{tabular}{|c|c|c|c|c|}
\hline Author & Study & Population & Serum (ng/ml) & $\mathrm{CSF}(\mathrm{ng} / \mathrm{ml})$ \\
\hline & & Ctrl $(n=20)$ & $334.9 \pm 93.9$ & \\
\hline \multirow[t]{2}{*}{ Siebert } & Diabetes Care. 2007 & $\begin{array}{l}\text { Diabetes mellitus type } 2 \\
(n=43)\end{array}$ & $319.7 \pm 107.04$ & \\
\hline & & $\operatorname{Ctrl}(n=43)$ & $550.54 \pm 187.99$ & \\
\hline \multirow[t]{2}{*}{ Cronin } & Neurology. 2006 & $\operatorname{ALS}(n=79)$ & $396.7 \pm 120.9$ & \\
\hline & & Ctrl $(n=72)$ & $334.6 \pm 106$ & \\
\hline \multirow[t]{2}{*}{ Kim } & Leukemia and Lymphoma. 2005 & Leukaemia $(n=43)$ & $277.6(145.9-533.7)$ & \\
\hline & & $\operatorname{Ctrl}(n=18)$ & $226(68-349.8)$ & \\
\hline \multirow[t]{2}{*}{ Molica } & Eur J Haematol. 2004 & Leukaemia $(n=77)$ & $295(74-1,700)$ & \\
\hline & & $\operatorname{Ctrl}(n=15)$ & $264(29-1,835)$ & \\
\hline \multirow[t]{2}{*}{ Hisai } & Clin Cancer Res. 2003 & $\begin{array}{l}\text { Hepatocellular carcinoma } \\
(n=39)\end{array}$ & $362.3 \pm 84.1$ & \\
\hline & & $\operatorname{Ctrl}(n=31)$ & $331.9 \pm 133.8$ & \\
\hline \multirow[t]{3}{*}{ Verstovsek } & Br J Haematol. 2001 & Leukaemia/myelodysplastic & Plasma & \\
\hline & & syndrome $(n=101)$ & $609.7(127.6-1,054.0)$ & \\
\hline & & $\operatorname{Ctrl}(n=11)$ & 197.1 & \\
\hline \multirow[t]{2}{*}{ Miyake } & Cancer. 1999 & Urothelial carcinoma $(n=135)$ & $434.86 \pm 186.02$ & \\
\hline & & $\operatorname{Ctrl}(n=52)$ & $337.5 \pm 71.4$ & \\
\hline
\end{tabular}

Data shown as mean $\pm \mathrm{SD}$ and (range) or median and [IQR]. Control values are shown in italics

spillover from serum expression due to systematic injuries. This is evident in the changes seen in Ang2. Whilst Ang2 levels in the serum were much below that of Ang1, they become substantially higher than Ang1 levels in CSF. This is not unexpected, as Ang1 is constitutively expressed in the maintenance of quiescent adult vessels, whilst Ang2 is only found at sites of active angiogenesis. Given the context of BSCB breakdown after SCI and the antagonistic role of Ang2 against Ang1, this suggests that this increase is indeed an active upregulation in the expression and/or secretion of Ang2 locally, which may indicate the destabilization of local vasculature and breakdown of BSCB after SCI.

Much of the current knowledge regarding the mechanisms of secondary injury has been deciphered in animal models of SCI, whilst the direct observation of human injuries is far less common. It is important to keep in mind when examining animal studies that there are considerable differences in both anatomy and physiology between such animal models and human injuries. For example, humans may be more susceptible to spinal cord ischemia compared to rodents because of the increased distance between segmental arteries that are exclusively dependent on diffusion from the capillary supply. Within the thoracic cord, anatomical differences also exist, with a 'watershed' region of the human thoracic cord dependent upon the ascending lumbar artery (and thus vulnerable to ischemia) as compared to the rodent thoracic cord which has sufficient collateral supply. Furthermore, the development of the progressive secondary injury is observably different between species with regards to cavitations and scarring. These differences may dampen the ability to translate a potential therapeutic treatment into the clinical setting. The reverse translation of information gathered from clinical studies back to the controlled environment of the laboratory could be crucial to extract the differences that exist between animal models and the clinical setting and accelerate the tedious process of clinical translation of pharmaceutical interventions for the treatment of SCI.

In conclusion, this article summarizes a portion of the published literature regarding the vascular injury that occurs after SCI and presents novel findings on the expression of three angiogenic proteins: Ang1, Ang2 and angiogenin in CSF and serum after acute human SCI. The intimate relationship of the neurovascular unit and its pathophysiology remains an important focus as a neuroprotective/neuroregenerative strategy for SCI and other CNS disorders alike.

Acknowledgements The authors gratefully acknowledge grant funding in support of this research from the Canadian Institutes for Health Research (CIHR), Craig Neilsen Foundation, Rick Hansen Institute and Michael Smith Foundation for Health Research (MSFHR). BKK holds a New Investigator award from CIHR and a Scholar award from MSFHR. 


\section{References}

1. Abbott NJ, Ronnback L, Hansson E. Astrocyte-endothelial interactions at the blood-brain barrier. Nat Rev Neurosci. 2006;7(1):41-53. doi:10.1038/nrn1824.

2. Abdel-Malak NA, Mofarrahi M, Mayaki D, Khachigian LM, Hussain SN. Early growth response-1 regulates angiopoietin-1induced endothelial cell proliferation, migration, and differentiation. Arterioscler Thromb Vasc Biol. 2009;29(2):209-16. doi:10.1161/ATVBAHA.108.181073.

3. Acharya KR, Shapiro R, Allen SC, Riordan JF, Vallee BL. Crystal structure of human angiogenin reveals the structural basis for its functional divergence from ribonuclease. Proc Natl Acad Sci USA. 1994;91(8):2915-9.

4. Adelson PD, Whalen MJ, Kochanek PM, Robichaud P, Carlos TM. Blood brain barrier permeability and acute inflammation in two models of traumatic brain injury in the immature rat: a preliminary report. Acta Neurochir Suppl. 1998;71:104-6.

5. Allen AR. Remarks on the histopathological changes in the spinal cord due to impact - an experimental study. J Nerv Ment Dis. 1914;41:141-7.

6. Anagnostopoulos A, Eleftherakis-Papaiakovou V, Kastritis E, Tsionos K, Bamias A, Meletis J, et al. Serum concentrations of angiogenic cytokines in Waldenstrom macroglobulinaemia: the ration of angiopoietin-1 to angiopoietin-2 and angiogenin correlate with disease severity. $\mathrm{Br}$ J Haematol. 2007;137 (6):560-8. doi:10.1111/j.1365-2141.2007.06609.x.

7. Andersson PB, Perry VH, Gordon S. The kinetics and morphological-characteristics of the macrophage microglial response to kainic acid-induced neuronal degeneration. Neuroscience. 1991;42(1):201-14.

8. Andersson PB, Perry VH, Gordon S. The acute inflammatory response to lipopolysaccharide in CNS parenchyma differs from that in other body-tissues. Neuroscience. 1992;48(1):169-86.

9. Armulik A, Genove G, Mae M, Nisancioglu MH, Wallgard E, Niaudet C, et al. Pericytes regulate the blood-brain barrier. Nature. 2010;468(7323):557-61. doi:10.1038/nature09522.

10. Attwell D, Laughlin SB. An energy budget for signaling in the grey matter of the brain. J Cereb Blood Flow Metab. 2001;21 (10):1133-45. doi:10.1097/00004647-200110000-00001.

11. Augustin HG, Koh GY, Thurston G, Alitalo K. Control of vascular morphogenesis and homeostasis through the angiopoietinTie system. Nat Rev Mol Cell Biol. 2009;10(3):165-77. doi:10.1038/nrm2639.

12. Baffert F, Le T, Thurston G, McDonald DM. Angiopoietin-1 decreases plasma leakage by reducing number and size of endothelial gaps in venules. Am J Physiol Heart Circ Physiol. 2006;290(1):H107-18. doi:10.1152/ajpheart.00542.2005.

13. Balentine JD. Pathology of experimental spinal cord trauma. I. The necrotic lesion as a function of vascular injury. Lab Invest. 1978;39(3):236-53.

14. Bartanusz V, Jezova D, Alajajian B, Digicaylioglu M. The blood-spinal cord barrier: morphology and clinical implications. Ann Neurol. 2011. doi:10.1002/ana.22421.

15. Barton WA, Tzvetkova D, Nikolov DB. Structure of the angiopoietin-2 receptor binding domain and identification of surfaces involved in Tie2 recognition. Structure. 2005;13 (5):825-32. doi:10.1016/j.str.2005.03.009.

16. Barton WA, Tzvetkova-Robev D, Miranda EP, Kolev MV, Rajashankar KR, Himanen JP, et al. Crystal structures of the Tie2 receptor ectodomain and the angiopoietin-2-Tie2 complex. Nat Struct Mol Biol. 2006;13(6):524-32. doi:10.1038/ nsmb1101.

17. Benton RL, Maddie MA, Minnillo DR, Hagg T, Whittemore SR. Griffonia simplicifolia isolectin B4 identifies a specific subpop- ulation of angiogenic blood vessels following contusive spinal cord injury in the adult mouse. J Comp Neurol. 2008;507 (1):1031-52. doi:10.1002/cne.21570.

18. Bhandari V, Elias JA. The role of angiopoietin 2 in hyperoxia-induced acute lung injury. Cell Cycle. 2007;6 (9):1049-52.

19. Bhandari V, Choo-Wing R, Lee CG, Zhu Z, Nedrelow JH, Chupp GL, et al. Hyperoxia causes angiopoietin 2-mediated acute lung injury and necrotic cell death. Nat Med. 2006;12 (11):1286-93. doi:10.1038/nm1494.

20. Billingham RE, Boswell T. Studies on the problem of corneal homografts. Proc Roy Soc Lond B Biol Sci. 1953;141(904):392.

21. Bolton B. The blood supply of the human spinal cord. J Neurol Psychiatr. 1939;2(2):137-48.

22. Bravo G, Rojas-Martinez R, Larios F, Hong E, CastanedaHernandez G, Rojas G, et al. Mechanisms involved in the cardiovascular alterations immediately after spinal cord injury. Life Sci. 2001;68(13):1527-34.

23. Brightman MW, Reese TS. Junctions between intimately apposed cell membranes in the vertebrate brain. J Cell Biol. 1969;40(3):648-77.

24. Cascone I, Audero E, Giraudo E, Napione L, Maniero F, Philips MR, et al. Tie-2-dependent activation of RhoA and Rac1 participates in endothelial cell motility triggered by angiopoietin-1. Blood. 2003;102(7):2482-90. doi:10.1182/ blood-2003-03-0670.

25. Casella GT, Marcillo A, Bunge MB, Wood PM. New vascular tissue rapidly replaces neural parenchyma and vessels destroyed by a contusion injury to the rat spinal cord. Exp Neurol. 2002;173(1):63-76. doi:10.1006/exnr.2001.7827.

26. Casella GT, Bunge MB, Wood PM. Endothelial cell loss is not a major cause of neuronal and glial cell death following contusion injury of the spinal cord. Exp Neurol. 2006;202(1):8-20. doi:10.1016/j.expneurol.2006.05.028.

27. Chan PH. Mitochondria and neuronal death/survival signaling pathways in cerebral ischemia. Neurochem Res. 2004;29 (11):1943-9.

28. Chen JX, Chen Y, DeBusk L, Lin W, Lin PC. Dual functional roles of Tie-2/angiopoietin in TNF-alpha-mediated angiogenesis. Am J Physiol Heart Circ Physiol. 2004;287(1):H187-95. doi:10.1152/ajpheart.01058.2003.

29. Choe JY, Park SH, Kim SK. Serum angiopoietin-1 level is increased in patients with Behcet's disease. Joint Bone Spine. 2010;77(4):340-4. doi:10.1016/j.jbspin.2010.01.014.

30. Crabtree B, Thiyagarajan N, Prior SH, Wilson P, Iyer S, Ferns T, et al. Characterization of human angiogenin variants implicated in amyotrophic lateral sclerosis. Biochemistry. 2007;46 (42):11810-8. doi:10.1021/bi701333h.

31. Cronin S, Greenway MJ, Ennis S, Kieran D, Green A, Prehn JH, et al. Elevated serum angiogenin levels in ALS. Neurology. 2006;67(10):1833-6. doi:10.1212/01.wnl.0000244466.46020.47.

32. Cserr HF, Knopf PM. Cervical lymphatics, the blood-brainbarrier and the immunoreactivity of the brain - a new view. Immunol Today. 1992;13(12):507-12.

33. Curran TP, Shapiro R, Riordan JF. Alteration of the enzymatic specificity of human angiogenin by site-directed mutagenesis. Biochemistry. 1993;32(9):2307-13.

34. Curran TP, Shapiro R, Riordan JF, Vallee BL. Modulation of the activity of angiogenin by mutagenesis at Asp-116. Biochim Biophys Acta. 1993;1202(2):281-6.

35. Dallabrida SM, Ismail N, Oberle JR, Himes BE, Rupnick MA. Angiopoietin-1 promotes cardiac and skeletal myocyte survival through integrins. Circ Res. 2005;96(4):e8-e24. doi:10.1161/01. RES.0000158285.57191.60.

36. Dallabrida SM, Ismail NS, Pravda EA, Parodi EM, Dickie R, Durand EM, et al. Integrin binding angiopoietin-1 monomers 
reduce cardiac hypertrophy. FASEB J. 2008;22(8):3010-23. doi:10.1096/fj.07-100966.

37. Daly C, Wong V, Burova E, Wei Y, Zabski S, Griffiths J, et al. Angiopoietin-1 modulates endothelial cell function and gene expression via the transcription factor FKHR (FOXO1). Genes Dev. 2004;18(9):1060-71. doi:10.1101/gad.1189704.

38. Daly C, Pasnikowski E, Burova E, Wong V, Aldrich TH, Griffiths $\mathrm{J}$, et al. Angiopoietin-2 functions as an autocrine protective factor in stressed endothelial cells. Proc Natl Acad Sci USA. 2006;103(42):15491-6. doi:10.1073/pnas.0607538103.

39. Davis S, Aldrich TH, Jones PF, Acheson A, Compton DL, Jain $\mathrm{V}$, et al. Isolation of angiopoietin-1, a ligand for the TIE2 receptor, by secretion-trap expression cloning. Cell. 1996;87 (7):1161-9.

40. Davis S, Papadopoulos N, Aldrich TH, Maisonpierre PC, Huang T, Kovac L, et al. Angiopoietins have distinct modular domains essential for receptor binding, dimerization and superclustering. Nat Struct Biol. 2003;10(1):38-44. doi: $10.1038 / \mathrm{nsb} 880$.

41. Donnelly DJ, Popovich PG. Inflammation and its role in neuroprotection, axonal regeneration and functional recovery after spinal cord injury. Exp Neurol. 2008;209(2):378-88. doi:10.1016/j.expneurol.2007.06.009.

42. Dray C, Rougon G, Debarbieux F. Quantitative analysis by in vivo imaging of the dynamics of vascular and axonal networks in injured mouse spinal cord. Proc Natl Acad Sci USA. 2009;106 (23):9459-64. doi:10.1073/pnas.0900222106.

43. Dumont DJ, Yamaguchi TP, Conlon RA, Rossant J, Breitman ML. tek, a novel tyrosine kinase gene located on mouse chromosome 4, is expressed in endothelial cells and their presumptive precursors. Oncogene. 1992;7(8):1471-80.

44. Dumont DJ, Gradwohl GJ, Fong GH, Auerbach R, Breitman ML. The endothelial-specific receptor tyrosine kinase, tek, is a member of a new subfamily of receptors. Oncogene. 1993;8 (5):1293-301.

45. Fanning AS, Jameson BJ, Jesaitis LA, Anderson JM. The tight junction protein ZO-1 establishes a link between the transmembrane protein occludin and the actin cytoskeleton. J Biol Chem. 1998;273(45):29745-53.

46. Farry A, Baxter D. The incidence and prevalence of spinal cord injury in Canada. Vancouver: Rick Hansen Institute and Urban Futures Institute; 2010.

47. Fenstermacher J, Gross P, Sposito N, Acuff V, Pettersen S, Gruber K. Structural and functional variations in capillary systems within the brain. Ann N Y Acad Sci. 1988;529:21-30.

48. Fett JW, Strydom DJ, Lobb RR, Alderman EM, Bethune JL, Riordan JF, et al. Isolation and characterization of angiogenin, an angiogenic protein from human carcinoma cells. Biochemistry. 1985;24(20):5480-6.

49. Fiedler U, Krissl T, Koidl S, Weiss C, Koblizek T, Deutsch U, et al. Angiopoietin-1 and angiopoietin-2 share the same binding domains in the Tie-2 receptor involving the first Ig-like loop and the epidermal growth factor-like repeats. J Biol Chem. 2003;278 (3):1721-7. doi:10.1074/jbc.M208550200.

50. Fiedler U, Scharpfenecker M, Koidl S, Hegen A, Grunow V, Schmidt JM, et al. The Tie-2 ligand angiopoietin-2 is stored in and rapidly released upon stimulation from endothelial cell Weibel-Palade bodies. Blood. 2004;103(11):4150-6. doi:10.1182/blood-2003-10-3685.

51. Fiedler U, Reiss Y, Scharpfenecker M, Grunow V, Koidl S, Thurston G, et al. Angiopoietin-2 sensitizes endothelial cells to TNF-alpha and has a crucial role in the induction of inflammation. Nat Med. 2006;12(2):235-9. doi:10.1038/nm1351.

52. Fujikawa K, de Aos Scherpenseel I, Jain SK, Presman E, Christensen RA, Varticovski L. Role of PI 3-kinase in angiopoietin-1-mediated migration and attachment-dependent survival of endothelial cells. Exp Cell Res. 1999;253(2):66372. doi:10.1006/excr.1999.4693.

53. Fukuhara S, Sako K, Minami T, Noda K, Kim HZ, Kodama T, et al. Differential function of Tie2 at cell-cell contacts and cellsubstratum contacts regulated by angiopoietin-1. Nat Cell Biol. 2008;10(5):513-26. doi:10.1038/ncb1714.

54. Furuse M, Hirase T, Itoh M, Nagafuchi A, Yonemura S, Tsukita S. Occludin: a novel integral membrane protein localizing at tight junctions. J Cell Biol. 1993;123(6 Pt 2):1777-88.

55. Furuse $M$, Itoh M, Hirase $T$, Nagafuchi A, Yonemura S, Tsukita S. Direct association of occludin with ZO-1 and its possible involvement in the localization of occludin at tight junctions. $\mathrm{J}$ Cell Biol. 1994;127(6 Pt 1):1617-26.

56. Furuse M, Sasaki H, Fujimoto K, Tsukita S. A single gene product, claudin-1 or -2 , reconstitutes tight junction strands and recruits occludin in fibroblasts. J Cell Biol. 1998;143(2):391401.

57. Fuxe J, Tabruyn S, Colton K, Zaid H, Adams A, Baluk P, et al. Pericyte requirement for anti-leak action of angiopoietin-1 and vascular remodeling in sustained inflammation. Am J Pathol. 2011;178:2897-909. doi:10.1016/j.ajpath.2011.02.008.

58. Galea I, Bechmann I, Perry VH. What is immune privilege (not)? Trends Immunol. 2007;28(1):12-8. doi:10.1016/J. It.2006.11.004.

59. Gamble JR, Drew J, Trezise L, Underwood A, Parsons M, Kasminkas L, et al. Angiopoietin-1 is an antipermeability and anti-inflammatory agent in vitro and targets cell junctions. Circ Res. 2000;87(7):603-7.

60. Gerzanich V, Woo SK, Vennekens R, Tsymbalyuk O, Ivanova S, Ivanov A, et al. De novo expression of Trpm4 initiates secondary hemorrhage in spinal cord injury. Nat Med. 2009;15(2):185-91. doi:10.1038/nm.1899.

61. Goritz C, Dias DO, Tomilin N, Barbacid M, Shupliakov O, Frisen J. A pericyte origin of spinal cord scar tissue. Science. 2011;333(6039):238-42. doi:10.1126/science.1203165.

62. Greenway MJ, Andersen PM, Russ C, Ennis S, Cashman S, Donaghy $\mathrm{C}$, et al. ANG mutations segregate with familial and 'sporadic' amyotrophic lateral sclerosis. Nat Genet. 2006;38 (4):411-3. doi:10.1038/ng1742.

63. Griffiths IR. Spinal cord blood flow after acute experimental cord injury in dogs. J Neurol Sci. 1976;27(2):247-59.

64. Griffiths IR, Burns N, Crawford AR. Early vascular changes in the spinal grey matter following impact injury. Acta Neuropathol. 1978;41(1):33-9.

65. Griffiths IR, Trench JG, Crawford RA. Spinal-cord blood-flow and conduction during experimental cord compression in normotensive and hypotensive dogs. J Neurosurg. 1979;50 (3):353-60.

66. Guha A, Tator $\mathrm{CH}$, Rochon J. Spinal cord blood flow and systemic blood pressure after experimental spinal cord injury in rats. Stroke. 1989;20(3):372-7.

67. Han S, Arnold SA, Sithu SD, Mahoney ET, Geralds JT, Tran P, et al. Rescuing vasculature with intravenous angiopoietin-1 and alpha $\mathrm{v}$ beta 3 integrin peptide is protective after spinal cord injury. Brain. 2010;133(Pt 4):1026-42. doi:10.1093/brain/ awq034.

68. Han SY, Jun JK, Lee CH, Park JS, Syn HC. Angiopoietin-2: a promising indicator for the occurrence of severe preeclampsia. Hypertens Pregnancy. 2010. doi:10.3109/ 10641955.2010.507844.

69. Harfouche R, Hussain SN. Signaling and regulation of endothelial cell survival by angiopoietin-2. Am J Physiol Heart Circ Physiol. 2006;291(4):H1635-45. doi:10.1152/ ajpheart.01318.2005.

70. Harfouche R, Hassessian HM, Guo Y, Faivre V, Srikant CB, Yancopoulos GD, et al. Mechanisms which mediate the 
antiapoptotic effects of angiopoietin-1 on endothelial cells. Microvasc Res. 2002;64(1):135-47. doi:10.1006/ mvre.2002.2421.

71. Harfouche R, Gratton JP, Yancopoulos GD, Noseda M, Karsan A, Hussain SN. Angiopoietin-1 activates both anti- and proapoptotic mitogen-activated protein kinases. FASEB J. 2003;17(11):1523-5. doi:10.1096/fj.02-0698fje.

72. Harfouche R, Malak NA, Brandes RP, Karsan A, Irani K, Hussain SN. Roles of reactive oxygen species in angiopoietin-1/ tie-2 receptor signaling. FASEB J. 2005;19(12):1728-30. doi:10.1096/fj.04-3621 fje.

73. Harrington JF, Messier AA, Levine A, Szmydynger-Chodobska J, Chodobski A. Shedding of tumor necrosis factor type 1 receptor after experimental spinal cord injury. J Neurotrauma. 2005;22(8):919-28. doi:10.1089/neu.2005.22.919.

74. Hartmann A, Kunz M, Kostlin S, Gillitzer R, Toksoy A, Brocker $\mathrm{EB}$, et al. Hypoxia-induced up-regulation of angiogenin in human malignant melanoma. Cancer Res. 1999;59(7):1578-83.

75. Hassler O. Blood supply to human spinal cord. A microangiographic study. Arch Neurol. 1966;15(3):302-7.

76. Hatalski CG, Hickey WF, Lipkin WI. Evolution of the immune response in the central nervous system following infection with Borna disease virus. J Neuroimmunol. 1998;90(2):137-42.

77. Hatalski CG, Hickey WF, Lipkin WI. Humoral immunity in the central nervous system of Lewis rats infected with Borna disease virus. J Neuroimmunol. 1998;90(2):128-36.

78. Hawryluk GW, Rowland J, Kwon BK, Fehlings MG. Protection and repair of the injured spinal cord: a review of completed, ongoing, and planned clinical trials for acute spinal cord injury. Neurosurg Focus. 2008;25(5):E14. doi:10.3171/ FOC.2008.25.11.E14.

79. Hayashi Y, Nomura M, Yamagishi S, Harada S, Yamashita J, Yamamoto $\mathrm{H}$. Induction of various blood-brain barrier properties in non-neural endothelial cells by close apposition to co-cultured astrocytes. Glia. 1997;19(1):13-26. doi:10.1002/(SICI)10981136(199701)19:1<13::AID-GLIA2>3.0.CO;2-B.

80. Helfrich I, Edler L, Sucker A, Thomas M, Christian S, Schadendorf D, et al. Angiopoietin-2 levels are associated with disease progression in metastatic malignant melanoma. Clin Cancer Res. 2009;15(4):1384-92. doi:10.1158/1078-0432.CCR08-1615.

81. Herrera JJ, Sundberg LM, Zentilin L, Giacca M, Narayana PA. Sustained expression of vascular endothelial growth factor and angiopoietin-1 improves blood-spinal cord barrier integrity and functional recovery after spinal cord injury. J Neurotrauma. 2010;27(11):2067-76. doi:10.1089/neu.2010.1403.

82. Hickey WF. Leukocyte traffic in the central nervous system: the participants and their roles. Semin Immunol. 1999;11(2):125-37.

83. Hickey WF, Hsu BL, Kimura H. Lymphocyte-T entry into the central-nervous-system. J Neurosci Res. 1991;28(2):254-60.

84. Hisai H, Kato J, Kobune M, Murakami T, Miyanishi K, Takahashi $\mathrm{M}$, et al. Increased expression of angiogenin in hepatocellular carcinoma in correlation with tumor vascularity. Clin Cancer Res. 2003;9(13):4852-9.

85. Holash JA, Noden DM, Stewart PA. Re-evaluating the role of astrocytes in blood-brain barrier induction. Dev Dyn. 1993;197 (1):14-25. doi:10.1002/aja.1001970103.

86. Holash J, Wiegand SJ, Yancopoulos GD. New model of tumor angiogenesis: dynamic balance between vessel regression and growth mediated by angiopoietins and VEGF. Oncogene. 1999;18(38):5356-62. doi:10.1038/sj.onc.1203035.

87. Holmin S, Mathiesen T. Intracerebral administration of interleukin-1 beta and induction of inflammation, apoptosis, and vasogenic edema. J Neurosurg. 2000;92(1):108-20.

88. Hori S, Ohtsuki S, Hosoya K, Nakashima E, Terasaki T. A pericyte-derived angiopoietin-1 multimeric complex induces occludin gene expression in brain capillary endothelial cells through Tie-2 activation in vitro. J Neurochem. 2004;89(2):50313. doi:10.1111/j.1471-4159.2004.02343.x.

89. Hsu CY, Hogan EL, Gadsden Sr RH, Spicer KM, Shi MP, Cox RD. Vascular permeability in experimental spinal cord injury. $J$ Neurol Sci. 1985;70(3):275-82.

90. Hu GF, Riordan JF. Angiogenin enhances actin acceleration of plasminogen activation. Biochem Biophys Res Commun. 1993;197(2):682-7. doi:10.1006/bbrc.1993.2533.

91. Hu GF, Chang SI, Riordan JF, Vallee BL. An angiogenin-binding protein from endothelial cells. Proc Natl Acad Sci USA. 1991;88 (6):2227-31.

92. Hu GF, Strydom DJ, Fett JW, Riordan JF, Vallee BL. Actin is a binding protein for angiogenin. Proc Natl Acad Sci USA. 1993;90(4):1217-21.

93. Hu G, Riordan JF, Vallee BL. Angiogenin promotes invasiveness of cultured endothelial cells by stimulation of cell-associated proteolytic activities. Proc Natl Acad Sci USA. 1994;91 (25):12096-100.

94. Hu GF, Riordan JF, Vallee BL. A putative angiogenin receptor in angiogenin-responsive human endothelial cells. Proc Natl Acad Sci USA. 1997;94(6):2204-9.

95. Huang L, Guo H, Cheng M, Zhao Y, Jin X. The kinetic change of the serum angiogenin level in patients with acute cerebral infarction. Eur Neurol. 2007;58(4):224-7. doi:10.1159/ 000107944.

96. Hughes DP, Marron MB, Brindle NP. The antiinflammatory endothelial tyrosine kinase Tie2 interacts with a novel nuclear factor-kappaB inhibitor ABIN-2. Circ Res. 2003;92(6):630-6. doi:10.1161/01.RES.0000063422.38690.DC.

97. Hynes RO. Integrins: versatility, modulation, and signaling in cell adhesion. Cell. 1992;69(1):11-25.

98. Ilzecka J. Cerebrospinal fluid angiogenin level in patients with amyotrophic lateral sclerosis. Acta Clin Croat. 2008;47(2):77-9.

99. Jaeger CB, Blight AR. Spinal cord compression injury in guinea pigs: structural changes of endothelium and its perivascular cell associations after blood-brain barrier breakdown and repair. Exp Neurol. 1997;144(2):381-99. doi:10.1006/exnr.1996.6405.

100. Janzer RC, Raff MC. Astrocytes induce blood-brain barrier properties in endothelial cells. Nature. 1987;325(6101):253-7. doi:10.1038/325253a0.

101. Joshi S, Khan R, Sharma M, Kumar L, Sharma A. Angiopoietin2: a potential novel diagnostic marker in multiple myeloma. Clin Biochem. 2011;44(8-9):590-5. doi:10.1016/j.clinbiochem.2011.01.010.

102. Kaptanoglu E, Beskonakli E, Solaroglu I, Kilinc A, Taskin Y. Magnesium sulfate treatment in experimental spinal cord injury: emphasis on vascular changes and early clinical results. Neurosurg Rev. 2003;26(4):283-7. doi:10.1007/s10143-003-0272-y.

103. Karapinar H, Esen O, Emiroglu Y, Akcakoyun M, Pala S, Kargin $\mathrm{R}$, et al. Serum levels of angiopoietin-1 in patients with pulmonary hypertension due to mitral stenosis. Heart Vessels. 2010;26:536-41. doi:10.1007/s00380-010-0092-2.

104. Kermode AG, Thompson AJ, Tofts P, Macmanus DG, Kendall BE, Kingsley DPE, et al. Breakdown of the blood-brain-barrier precedes symptoms and other MRI signs of new lesions in multiple-sclerosis-pathogenetic and clinical implications. Brain. 1990;113:1477-89.

105. Kieran D, Sebastia J, Greenway MJ, King MA, Connaughton D, Concannon $\mathrm{CG}$, et al. Control of motoneuron survival by angiogenin. J Neurosci. 2008;28(52):14056-61. doi:10.1523/ JNEUROSCI.3399-08.2008.

106. Kim I, Kim HG, Moon SO, Chae SW, So JN, Koh KN, et al. Angiopoietin-1 induces endothelial cell sprouting through the activation of focal adhesion kinase and plasmin secretion. Circ Res. 2000;86(9):952-9. 
107. Kim I, Kim HG, So JN, Kim JH, Kwak HJ, Koh GY. Angiopoietin-1 regulates endothelial cell survival through the phosphatidylinositol 3'-kinase/Akt signal transduction pathway. Circ Res. 2000;86(1):24-9.

108. Kim I, Kim JH, Moon SO, Kwak HJ, Kim NG, Koh GY. Angiopoietin-2 at high concentration can enhance endothelial cell survival through the phosphatidylinositol 3'-kinase/Akt signal transduction pathway. Oncogene. 2000;19(39):4549-52. doi:10.1038/sj.onc.1203800.

109. Kim I, Kim JH, Ryu YS, Liu M, Koh GY. Tumor necrosis factoralpha upregulates angiopoietin-2 in human umbilical vein endothelial cells. Biochem Biophys Res Commun. 2000;269 (2):361-5. doi:10.1006/bbrc.2000.2296.

110. Kim I, Moon SO, Park SK, Chae SW, Koh GY. Angiopoietin-1 reduces VEGF-stimulated leukocyte adhesion to endothelial cells by reducing ICAM-1, VCAM-1, and E-selectin expression. Circ Res. 2001;89(6):477-9.

111. Kim I, Oh JL, Ryu YS, So JN, Sessa WC, Walsh K, et al. Angiopoietin-1 negatively regulates expression and activity of tissue factor in endothelial cells. FASEB J. 2002;16(1):126-8. doi:10.1096/fj.01-0556fje.

112. Kim JG, Sohn SK, Kim DH, Baek JH, Lee NY, Suh JS, et al. Clinical implications of angiogenic factors in patients with acute or chronic leukemia: hepatocyte growth factor levels have prognostic impact, especially in patients with acute myeloid leukemia. Leuk Lymphoma. 2005;46(6):885-91. doi:10.1080/ 10428190500054491

113. Kim KT, Choi HH, Steinmetz MO, Maco B, Kammerer RA, Ahn $\mathrm{SY}$, et al. Oligomerization and multimerization are critical for angiopoietin-1 to bind and phosphorylate Tie2. J Biol Chem. 2005;280(20):20126-31. doi:10.1074/jbc.M500292200.

114. Kim HM, Kang DK, Kim HY, Kang SS, Chang SI. Angiogenininduced protein kinase B/Akt activation is necessary for angiogenesis but is independent of nuclear translocation of angiogenin in HUVE cells. Biochem Biophys Res Commun. 2007;352(2):509-13. doi:10.1016/j.bbrc.2006.11.047.

115. Kishimoto K, Liu S, Tsuji T, Olson KA, Hu GF. Endogenous angiogenin in endothelial cells is a general requirement for cell proliferation and angiogenesis. Oncogene. 2005;24(3):445-56. doi:10.1038/sj.onc.1208223.

116. Knopf PM, Harling-Berg CJ, Cserr HF, Basu D, Sirulnick EJ, Nolan SC, et al. Antigen-dependent intrathecal antibody synthesis in the normal rat brain: tissue entry and local retention of antigen-specific B cells. J Immunol. 1998;161(2):692-701.

117. Koblizek TI, Weiss C, Yancopoulos GD, Deutsch U, Risau W. Angiopoietin-1 induces sprouting angiogenesis in vitro. Curr Biol. 1998;8(9):529-32.

118. Kurachi K, Davie EW, Strydom DJ, Riordan JF, Vallee BL. Sequence of the cDNA and gene for angiogenin, a human angiogenesis factor. Biochemistry. 1985;24(20):5494-9.

119. Kwak HJ, So JN, Lee SJ, Kim I, Koh GY. Angiopoietin-1 is an apoptosis survival factor for endothelial cells. FEBS Lett. 1999;448(2-3):249-53.

120. Kwon BK, Tetzlaff W, Grauer JN, Beiner J, Vaccaro AR. Pathophysiology and pharmacologic treatment of acute spinal cord injury. Spine J. 2004;4(4):451-64. doi:10.1016/j. spinee.2003.07.007.

121. Kwon BK, Curt A, Belanger LM, Bernardo A, Chan D, Markez $\mathrm{JA}$, et al. Intrathecal pressure monitoring and cerebrospinal fluid drainage in acute spinal cord injury: a prospective randomized trial. J Neurosurg Spine. 2009;10(3):181-93. doi:10.3171/ 2008.10.SPINE08217.

122. Kwon BK, Okon E, Hillyer J, Mann C, Baptiste D, Weaver LC, et al. A systematic review of non-invasive pharmacologic neuroprotective treatments for acute spinal cord injury. J Neurotrauma. 2010;28:1545-88. doi:10.1089/neu.2009.1149.
123. Kwon BK, Okon EB, Plunet W, Baptiste D, Fouad K, Hillyer J, et al. A systematic review of directly applied biologic therapies for acute spinal cord injury. J Neurotrauma. 2010;28:1589-610. doi:10.1089/neu.2009.1150.

124. Kwon BK, Stammers AM, Belanger LM, Bernardo A, Chan D, Bishop CM, et al. Cerebrospinal fluid inflammatory cytokines and biomarkers of injury severity in acute human spinal cord injury. J Neurotrauma. 2010;27(4):669-82. doi:10.1089/ neu.2009.1080.

125. Lee OH, Xu J, Fueyo J, Fuller GN, Aldape KD, Alonso MM, et al. Expression of the receptor tyrosine kinase Tie2 in neoplastic glial cells is associated with integrin beta1-dependent adhesion to the extracellular matrix. Mol Cancer Res. 2006;4(12):915-26. doi:10.1158/1541-7786.MCR-06-0184.

126. Lee SW, Kim WJ, Jun HO, Choi YK, Kim KW. Angiopoietin-1 reduces vascular endothelial growth factor-induced brain endothelial permeability via upregulation of ZO-2. Int J Mol Med. 2009;23(2):279-84.

127. Lipton SA, Rosenberg PA. Excitatory amino-acids as a final common pathway for neurologic disorders. $\mathrm{N}$ Engl J Med. 1994;330(9):613-22.

128. Liu S, Yu D, Xu ZP, Riordan JF, Hu GF. Angiogenin activates Erk1/2 in human umbilical vein endothelial cells. Biochem Biophys Res Commun. 2001;287(1):305-10. doi:10.1006/ bbrc.2001.5568.

129. Lobov IB, Brooks PC, Lang RA. Angiopoietin-2 displays VEGF-dependent modulation of capillary structure and endothelial cell survival in vivo. Proc Natl Acad Sci USA. 2002;99 (17):11205-10. doi:10.1073/pnas.172161899.

130. Loy DN, Crawford CH, Darnall JB, Burke DA, Onifer SM, Whittemore SR. Temporal progression of angiogenesis and basal lamina deposition after contusive spinal cord injury in the adult rat. J Comp Neurol. 2002;445(4):308-24. doi:10.1002/ cne.10168.

131. Lukacova N, Halat G, Chavko M, Marsala J. Ischemiareperfusion injury in the spinal cord of rabbits strongly enhances lipid peroxidation and modifies phospholipid profiles. Neurochem Res. 1996;21(8):869-73.

132. Maisonpierre PC, Suri C, Jones PF, Bartunkova S, Wiegand SJ, Radziejewski C, et al. Angiopoietin-2, a natural antagonist for Tie2 that disrupts in vivo angiogenesis. Science. 1997;277 (5322):55-60.

133. Mandriota SJ, Pepper MS. Regulation of angiopoietin- 2 mRNA levels in bovine microvascular endothelial cells by cytokines and hypoxia. Circ Res. 1998;83(8):852-9.

134. Martin-Padura I, Lostaglio S, Schneemann M, Williams L, Romano M, Fruscella P, et al. Junctional adhesion molecule, a novel member of the immunoglobulin superfamily that distributes at intercellular junctions and modulates monocyte transmigration. J Cell Biol. 1998;142(1):117-27.

135. Martirosyan NL, Feuerstein JS, Theodore N, Cavalcanti DD, Spetzler RF, Preul MC. Blood supply and vascular reactivity of the spinal cord under normal and pathological conditions. J Neurosurg Spine. 2011;15:238-51. doi:10.3171/2011.4. SPINE10543.

136. Mautes AE, Weinzierl MR, Donovan F, Noble LJ. Vascular events after spinal cord injury: contribution to secondary pathogenesis. Phys Ther. 2000;80(7):673-87.

137. Maxwell K, Berliner JA, Cancilla PA. Induction of gammaglutamyl transpeptidase in cultured cerebral endothelial cells by a product released by astrocytes. Brain Res. 1987;410(2):309-14.

138. Miyake H, Hara I, Yamanaka K, Gohji K, Arakawa S, Kamidono $\mathrm{S}$. Increased angiogenin expression in the tumor tissue and serum of urothelial carcinoma patients is related to disease progression and recurrence. Cancer. 1999;86(2):316-24. doi:10.1002/(SICI) 1097-0142(19990715)86:2<316::AID-CNCR16>3.0.CO;2-T. 
139. Moenner M, Gusse M, Hatzi E, Badet J. The widespread expression of angiogenin in different human cells suggests a biological function not only related to angiogenesis. Eur $\mathrm{J}$ Biochem. 1994;226(2):483-90.

140. Molica S, Vitelli G, Levato D, Giannarelli D, Vacca A, Cuneo A, et al. Serum angiogenin is not elevated in patients with early Bcell chronic lymphocytic leukemia but is prognostic factor for disease progression. Eur J Haematol. 2004;73(1):36-42. doi:10.1111/j.1600-0609.2004.00269.x.

141. Moreau C, Gosset P, Brunaud-Danel V, Lassalle P, Degonne B, Destee A, et al. CSF profiles of angiogenic and inflammatory factors depend on the respiratory status of ALS patients. Amyotroph Lateral Scler. 2009;10(3):175-81. doi:10.1080/ 17482960802651725.

142. Moroianu J, Riordan JF. Nuclear translocation of angiogenin in proliferating endothelial cells is essential to its angiogenic activity. Proc Natl Acad Sci USA. 1994;91(5):1677-81.

143. Mukouyama YS, Shin D, Britsch S, Taniguchi M, Anderson DJ. Sensory nerves determine the pattern of arterial differentiation and blood vessel branching in the skin. Cell. 2002;109(6):693705.

144. Nakamura M, Yamabe H, Osawa H, Nakamura N, Shimada M, Kumasaka R, et al. Hypoxic conditions stimulate the production of angiogenin and vascular endothelial growth factor by human renal proximal tubular epithelial cells in culture. Nephrol Dial Transplant. 2006;21(6):1489-95. doi:10.1093/ndt/gfl041.

145. Nelson E, Gertz SD, Rennels ML, Ducker TB, Blaumanis OR. Spinal cord injury. The role of vascular damage in the pathogenesis of central hemorrhagic necrosis. Arch Neurol. 1977;34(6):332-3.

146. Ng MT, Kwon, Brian K. Pharmacologic treatments for spinal cord injury. Spine trauma. 2nd ed. Chicago: American Academy of Orthopaedic Surgeons; 2010.

147. Noble LJ, Wrathall JR. Distribution and time course of protein extravasation in the rat spinal cord after contusive injury. Brain Res. 1989;482(1):57-66.

148. Oh H, Takagi H, Suzuma K, Otani A, Matsumura M, Honda Y. Hypoxia and vascular endothelial growth factor selectively upregulate angiopoietin-2 in bovine microvascular endothelial cells. J Biol Chem. 1999;274(22):15732-9.

149. Oldendorf WH, Cornford ME, Brown WJ. The large apparent work capability of the blood-brain barrier: a study of the mitochondrial content of capillary endothelial cells in brain and other tissues of the rat. Ann Neurol. 1977;1(5):409-17. doi:10.1002/ana.410010502.

150. Papapetropoulos A, Garcia-Cardena G, Dengler TJ, Maisonpierre PC, Yancopoulos GD, Sessa WC. Direct actions of angiopoietin-1 on human endothelium: evidence for network stabilization, cell survival, and interaction with other angiogenic growth factors. Lab Invest. 1999;79(2):213-23.

151. Papapetropoulos A, Fulton D, Mahboubi K, Kalb RG, O'Connor DS, Li F, et al. Angiopoietin-1 inhibits endothelial cell apoptosis via the Akt/survivin pathway. J Biol Chem. 2000;275(13):91025.

152. Patel JV, Sosin M, Gunarathne A, Hussain I, Davis RC, Hughes EA, et al. Elevated angiogenin levels in chronic heart failure. Ann Med. 2008;40:474-9. doi:10.1080/07853890802001419.

153. Pichiule P, Chavez JC, LaManna JC. Hypoxic regulation of angiopoietin-2 expression in endothelial cells. J Biol Chem. 2004;279(13):12171-80. doi:10.1074/jbc.M305146200.

154. Popovich PG, Horner PJ, Mullin BB, Stokes BT. A quantitative spatial analysis of the blood-spinal cord barrier. I. Permeability changes after experimental spinal contusion injury. Exp Neurol. 1996;142(2):258-75. doi:10.1006/exnr.1996.0196.

155. Procopio WN, Pelavin PI, Lee WM, Yeilding NM. Angiopoietin1 and -2 coiled coil domains mediate distinct homo-oligomerization patterns, but fibrinogen-like domains mediate ligand activity. J Biol Chem. 1999;274(42):30196-201.

156. Ramsauer M, Krause D, Dermietzel R. Angiogenesis of the blood-brain barrier in vitro and the function of cerebral pericytes. FASEB J. 2002;16(10):1274-6. doi:10.1096/fj.010814fje.

157. Reed BY, Masoumi A, Elhassan E, McFann K, Cadnapaphornchai MA, Maahs DM, et al. Angiogenic growth factors correlate with disease severity in young patients with autosomal dominant polycystic kidney disease. Kidney Int. 2011;79(1):128-34. doi:10.1038/ki.2010.355.

158. Reese TS, Karnovsky MJ. Fine structural localization of a blood-brain barrier to exogenous peroxidase. J Cell Biol. 1967;34(1):207-17.

159. Risling M, Linda H, Cullheim S, Franson P. A persistent defect in the blood-brain barrier after ventral funiculus lesion in adult cats: implications for CNS regeneration? Brain Res. 1989;494 (1):13-21.

160. Ritz MF, Graumann U, Gutierrez B, Hausmann O. Traumatic spinal cord injury alters angiogenic factors and TGF-beta1 that may affect vascular recovery. Curr Neurovasc Res. 2010;7 (4):301-10.

161. Rowland JW, Hawryluk GW, Kwon B, Fehlings MG. Current status of acute spinal cord injury pathophysiology and emerging therapies: promise on the horizon. Neurosurg Focus. 2008;25(5): E2. doi:10.3171/FOC.2008.25.11.E2.

162. Saharinen P, Eklund L, Miettinen J, Wirkkala R, Anisimov A, Winderlich M, et al. Angiopoietins assemble distinct Tie2 signalling complexes in endothelial cell-cell and cell-matrix contacts. Nat Cell Biol. 2008;10(5):527-37. doi:10.1038/ncb1715.

163. Savettieri G, Di Liegro I, Catania C, Licata L, Pitarresi GL, D'Agostino S, et al. Neurons and ECM regulate occludin localization in brain endothelial cells. Neuroreport. 2000;11 (5):1081-4.

164. Schanne FAX, Kane AB, Young EE, Farber JL. Calcium dependence of toxic cell-death - final common pathway. Science. 1979;206(4419):700-2.

165. Scharpfenecker M, Fiedler U, Reiss Y, Augustin HG. The Tie-2 ligand angiopoietin-2 destabilizes quiescent endothelium through an internal autocrine loop mechanism. J Cell Sci. 2005;118(Pt 4):771-80. doi:10.1242/jcs.01653.

166. Schulze C, Firth JA. Interendothelial junctions during bloodbrain barrier development in the rat: morphological changes at the level of individual tight junctional contacts. Brain Res Dev Brain Res. 1992;69(1):85-95.

167. Schutzer SE, Liu T, Natelson BH, Angel TE, Schepmoes AA, Purvine SO, et al. Establishing the proteome of normal human cerebrospinal fluid. PLoS One. 2010;5(6):e10980. doi:10.1371/ journal.pone.0010980.

168. Sebastia J, Kieran D, Breen B, King MA, Netteland DF, Joyce $\mathrm{D}$, et al. Angiogenin protects motoneurons against hypoxic injury. Cell Death Differ. 2009;16(9):1238-47. doi:10.1038/ cdd.2009.52.

169. Sedlakova R, Shivers RR, Del Maestro RF. Ultrastructure of the blood-brain barrier in the rabbit. J Submicrosc Cytol Pathol. 1999;31(1):149-61.

170. Senter HJ, Venes JL. Altered blood flow and secondary injury in experimental spinal cord trauma. J Neurosurg. 1978;49(4):56978. doi:10.3171/jns.1978.49.4.0569.

171. Senter HJ, Venes JL. Loss of autoregulation and posttraumatic ischemia following experimental spinal cord trauma. J Neurosurg. 1979;50(2):198-206. doi:10.3171/jns.1979.50.2.0198.

172. Shapiro R, Vallee BL. Site-directed mutagenesis of histidine-13 and histidine-114 of human angiogenin. Alanine derivatives inhibit angiogenin-induced angiogenesis. Biochemistry. 1989;28 (18):7401-8. 
173. Shapiro R, Fox EA, Riordan JF. Role of lysines in human angiogenin: chemical modification and site-directed mutagenesis. Biochemistry. 1989;28(4):1726-32.

174. Siebert J, Reiwer-Gostomska M, Babinska Z, Mysliwska J, Mysliwski A, Skopinska-Rozewska E, et al. Low serum angiogenin concentrations in patients with type 2 diabetes. Diabetes Care. 2007;30(12):3086-7. doi:10.2337/Dc07-0629.

175. Simard JM, Tsymbalyuk O, Ivanov A, Ivanova S, Bhatta S, Geng Z, et al. Endothelial sulfonylurea receptor 1-regulated NC Ca-ATP channels mediate progressive hemorrhagic necrosis following spinal cord injury. J Clin Invest. 2007;117(8):210513. doi:10.1172/JCI32041

176. Anonymous. Spinal cord injury fact and figures at a glance [database on the Internet]. National Spinal Cord Injury Statistical Center. 2011. Accessed: 27 Apr 2011

177. Stevenson BR, Siliciano JD, Mooseker MS, Goodenough DA. Identification of ZO-1: a high molecular weight polypeptide associated with the tight junction (zonula occludens) in a variety of epithelia. J Cell Biol. 1986;103(3):755-66.

178. Stratmann A, Risau W, Plate KH. Cell type-specific expression of angiopoietin-1 and angiopoietin-2 suggests a role in glioblastoma angiogenesis. Am J Pathol. 1998;153(5):1459-66. doi:10.1016/S0002-9440(10)65733-1.

179. Strydom DJ, Fett JW, Lobb RR, Alderman EM, Bethune JL, Riordan JF, et al. Amino acid sequence of human tumor derived angiogenin. Biochemistry. 1985;24(20):5486-94.

180. Subramanian V, Crabtree B, Acharya KR. Human angiogenin is a neuroprotective factor and amyotrophic lateral sclerosis associated angiogenin variants affect neurite extension/pathfinding and survival of motor neurons. Hum Mol Genet. 2008;17(1):130 49. doi: $10.1093 / \mathrm{hmg} / \mathrm{ddm} 290$

181. Sundberg C, Kowanetz M, Brown LF, Detmar M, Dvorak HF. Stable expression of angiopoietin-1 and other markers by cultured pericytes: phenotypic similarities to a subpopulation of cells in maturing vessels during later stages of angiogenesis in vivo. Lab Invest. 2002;82(4):387-401.

182. Takigawa T, Yonezawa T, Yoshitaka T, Minaguchi J, Kurosaki M, Tanaka M, et al. Separation of the perivascular basement membrane provides a conduit for inflammatory cells in a mouse spinal cord injury model. J Neurotrauma. 2010;27(4):739-51. doi:10.1089/neu.2009.1111.

183. Tator $\mathrm{CH}$. Hemodynamic issues and vascular factors in acute experimental spinal cord injury. J Neurotrauma. 1992;9(2):139 40. discussion 41 .

184. Tator CH, Koyanagi I. Vascular mechanisms in the pathophysiology of human spinal cord injury. J Neurosurg. 1997;86 (3):483-92. doi:10.3171/jns.1997.86.3.0483.

185. Tetzlaff W, Okon EB, Karimi-Abdolrezaee S, Hill CE, Sparling JS, Plemel JR, et al. A systematic review of cellular transplantation therapies for spinal cord injury. $J$ Neurotrauma. 2010;28:1611-82. doi:10.1089/neu.2009.1177.

186. Thomas M, Augustin HG. The role of the angiopoietins in vascular morphogenesis. Angiogenesis. 2009;12(2):125-37. doi:10.1007/s10456-009-9147-3.

187. Tsuji T, Sun Y, Kishimoto K, Olson KA, Liu S, Hirukawa S, et al. Angiogenin is translocated to the nucleus of HeLa cells and is involved in ribosomal RNA transcription and cell proliferation. Cancer Res. 2005;65(4):1352-60. doi:10.1158/0008-5472.CAN04-2058.

188. Turnbull IM. Microvasculature of the human spinal cord. J Neurosurg. 1971;35(2):141-7. doi:10.3171/jns.1971.35.2.0141.

189. Turnbull IM. Chapter 5. Blood supply of the spinal cord: normal and pathological considerations. Clin Neurosurg. 1973;20:56-84.
190. Turnbull IM, Brieg A, Hassler O. Blood supply of cervical spinal cord in man. A microangiographic cadaver study. J Neurosurg. 1966;24(6):951-65. doi:10.3171/jns.1966.24.6.0951.

191. van den Berg MEL, Castellote JM, Mahillo-Fernandez I, de Pedro-Cuesta J. Incidence of spinal cord injury worldwide: a systematic review. Neuroepidemiology. 2010;34(3):184-92. doi:10.1159/000279335.

192. Verstovsek S, Kantarjian H, Aguayo A, Manshouri T, Freireich E, Keating $M$, et al. Significance of angiogenin plasma concentrations in patients with acute myeloid leukaemia and advanced myelodysplastic syndrome. Br J Haematol. 2001;114 (2):290-5.

193. Wang CX, Olschowka JA, Wrathall JR. Increase of interleukin1 beta mRNA and protein in the spinal cord following experimental traumatic injury in the rat. Brain Res. 1997;759(2):190-6.

194. Whetstone WD, Hsu JY, Eisenberg M, Werb Z, NobleHaeusslein LJ. Blood-spinal cord barrier after spinal cord injury: relation to revascularization and wound healing. J Neurosci Res. 2003;74(2):227-39. doi:10.1002/jnr.10759.

195. Witzenbichler B, Maisonpierre PC, Jones P, Yancopoulos GD, Isner JM. Chemotactic properties of angiopoietin-1 and -2, ligands for the endothelial-specific receptor tyrosine kinase Tie2. J Biol Chem. 1998;273(29):18514-21.

196. Wong GHW, Bartlett P, Campbell I, Georgiou H, Schrader J. Inducible expression of $\mathrm{H}-2$ and Ia antigens on brain-cells and pancreatic-islet cells by a T-cell lymphokine, interferon-gamma. Lymphokine Res. 1984;3(4):282.

197. Wong AL, Haroon ZA, Werner S, Dewhirst MW, Greenberg CS, Peters KG. Tie2 expression and phosphorylation in angiogenic and quiescent adult tissues. Circ Res. 1997;81(4):567-74.

198. Wrathall JR, Teng YD, Choiniere D. Amelioration of functional deficits from spinal cord trauma with systemically administered NBQX, an antagonist of non-N-methyl-D-aspartate receptors. Exp Neurol. 1996;137(1):119-26.

199. Wu D, Yu W, Kishikawa H, Folkerth RD, Iafrate AJ, Shen Y, et al. Angiogenin loss-of-function mutations in amyotrophic lateral sclerosis. Ann Neurol. 2007;62(6):609-17. doi:10.1002/ ana.21221.

200. Xu Y, Yu Q. Angiopoietin-1, unlike angiopoietin-2, is incorporated into the extracellular matrix via its linker peptide region. $\mathrm{J}$ Biol Chem. 2001;276(37):34990-8. doi:10.1074/jbc. M103661200.

201. Xu Z, Monti DM, Hu G. Angiogenin activates human umbilical artery smooth muscle cells. Biochem Biophys Res Commun. 2001;285(4):909-14. doi:10.1006/bbrc.2001.5255.

202. Yamakawa M, Liu LX, Date T, Belanger AJ, Vincent KA, Akita GY, et al. Hypoxia-inducible factor-1 mediates activation of cultured vascular endothelial cells by inducing multiple angiogenic factors. Circ Res. 2003;93(7):664-73. doi:10.1161/01. RES.0000093984.48643.D7.

203. Yancopoulos GD, Davis S, Gale NW, Rudge JS, Wiegand SJ, Holash J. Vascular-specific growth factors and blood vessel formation. Nature. 2000;407(6801):242-8. doi:10.1038/ 35025215 .

204. Zhang Z, Guth L. Experimental spinal cord injury: Wallerian degeneration in the dorsal column is followed by revascularization, glial proliferation, and nerve regeneration. Exp Neurol. 1997;147(1):159-71. doi:10.1006/exnr.1997.6590.

205. Zhang J, Fukuhara S, Sako K, Takenouchi T, Kitani H, Kume T, et al. Angiopoietin-1/Tie2 signal augments basal Notch signal controlling vascular quiescence by inducing delta-like 4 expression through AKT-mediated activation of beta-catenin. J Biol Chem. 2011;286(10):8055-66. doi:10.1074/jbc.M110.192641. 